\title{
Status of BIPV and BAPV System for Less Energy-Hungry Building in India-A Review
}

\author{
Pranavamshu Reddy ${ }^{1}$, M. V. N. Surendra Gupta ${ }^{2}$, Srijita Nundy ${ }^{3}$, A. Karthick ${ }^{4}(1)$ and \\ Aritra Ghosh 5,*(D)
}

1 Electronics and Communication Engineering, SASTRA University, Tirumalaisamudram Thanjavur 613401, Tamil Nadu, India; pranavamshu4@gmail.com

2 Academy of Scientific and Innovative Research, CSIR-SERC, Chennai 600113, Tamil Nadu, India; mvnsgupta4805@gmail.com

3 School of Advanced Materials Science and Engineering, Sungkyunkwan University, Suwon 16419, Korea; srijita.31121990@gmail.com

4 Department of Electrical and Electronics Engineering, KPR Institute of Engineering and Technology, Avinashi Road, Arasur, Coimbatore 641 407, Tamilnadu, India; karthick.power@gmail.com

5 Environment and Sustainability Institute (ESI), University of Exeter, Penryn Campus, Penryn TR10 9FE, UK

* Correspondence: a.ghosh@exeter.ac.uk

Received: 25 February 2020; Accepted: 24 March 2020; Published: 29 March 2020

check for updates

\begin{abstract}
The photovoltaic (PV) system is one of the most promising technologies that generate benevolent electricity. Therefore, fossil fuel-generated electric power plants, that emit an enormous amount of greenhouse gases, can be replaced by the PV power plant. However, due to its lower efficiency than a traditional power plant, and to generate equal amount of power, a large land area is required for the PV power plant. Also, transmission and distribution losses are intricate issues for PV power plants. Therefore, the inclusion of PV into a building is one of the holistic approaches which reduce the necessity for such large land areas. Building-integrated and building attached/applied are the two types where PV can be included in the building. Building applied/attached PV(BAPV) indicates that the PV system is added/attached or applied to a building, whereas, building integrated PV (BIPV) illustrates the concept of replacing the traditional building envelop, such as window, wall, roof by PV. In India, applying PV on a building is growing due to India's solar mission target for 2022. In 2015, through Jawaharlal Nehru National Solar Mission, India targeted to achieve 100 GW PV power of which $40 \mathrm{GW}$ will be acquired from roof-integrated PV by 2022. By the end of December 2019, India achieved 33.7 GW total installed PV power. Also, green/zero energy/and sustainable buildings are gaining significance in India due to rapid urbanization. However, BIPV system is rarely used in India which is likely due to a lack of government support and public awareness. This work reviewed the status of BIPV/BAPV system in India. The BIPV window system can probably be the suitable BIPV product for Indian context to reduce the building's HVAC load.
\end{abstract}

Keywords: India; BIPV/BAPV; BIPV-Glazing; JNNSM; MNRE; Zero energy-building

\section{Introduction}

India's energy consumption has increased to 931 billion $\mathrm{kWh}$ which is double than of the level marked in the year 1990 making it one of the largest energy consumers in the world along with China, the USA and, Russia. In 2014, India's per capita electricity consumption was $900 \mathrm{kWh}$ which was $1 / 3$ of the average worldwide consumption [1,2]. Also, compared to 1971, Indian per capita energy use has increased from 3116.84 to $7408.31 \mathrm{kWh}$ in 2014 . India's energy sources primarily depend on non-renewable coal-based sources which contribute to a massive amount of greenhouse gases [3-5]. 
Currently, India is facing urbanization due to the migration of people into larger cities from smaller towns and villages. This transition enhances the necessity of developing new buildings. During 2014-2015, India consumed almost 840 million $\mathrm{m}^{2}$ floor space for commercial use. Buildings in India, consume $29 \%$ of the total energy, of which residential contributes to $20 \%$ and commercial to $9 \%$ [6]. In residential buildings, lighting and space cooling accounts to one-third of the energy consumption (1-3 kWh/m $\left./ \mathrm{m}^{2} / \mathrm{month}\right)$, whereas commercial buildings consume two-third of the total energy (5-25 $\mathrm{kWh} / \mathrm{m}^{2} /$ month) [7]. The phenomenal growth in the building sector will be witnessed by the year 2030 with an annual building rate of 700-900 million sq. $\mathrm{m}$. These buildings consume a considerable amount of energy for heating, ventilation and air conditioning (HVAC) load demand. Further, the indoor air condition rate is growing at a rate of 30\% every year. Projected energy usage for 2050, with the current scenario, shows an 85\% increment compared to the energy level in 2005 [8].

The present energy consumption scenario, along with future projections, has forced India to take some necessary actions. In 2015, the international energy association (IEA) has set a target to limit the ambient temperature increment to below $2{ }^{\circ} \mathrm{C}$ than the pre-industrial levels. Hence, India should focus on finding out the energy-efficient ways to generate power and also reduce building energy consumption rates. Fortunately, India is blessed with high solar radiation, which receives 6 billion GWh equivalent energy potential per year. The average incident solar radiation in India is $5.1 \mathrm{kWh} / \mathrm{m}^{2} /$ day (with large regional differences). This makes India deploy solar photovoltaic (PV) technology to meet the IEA target. The PV device is one of the most promising renewable energy technologies, which converts solar energy into environment-friendly electrical energy by using abundant incident solar radiation. Replacing fossil fuel-generated power by secure, clean and suitable PV generated power can mitigate issues like climatic changes [9,10].

The Ministry of Power, which controls the power sector in India, created an impressive mission through Jawaharlal Nehru National Solar Mission (JNNSM). Previously, JNNSM has set a target to install a PV capacity of $22 \mathrm{GW}$ by the year 2022 which later increased to a more ambitious target of $100 \mathrm{GW}$ [11]. Subsequently, to reduce building energy consumption and generate power from renewable sources in the buildings; zero energy buildings (ZEB) or net-zero energy buildings are also getting a promotion. Hence, addition of the PV system into the building is one of the most holistic approaches, where, PV will generate a benevolent amount of energy, sufficient for the building-energy requirements. The inclusion of PV technologies into buildings include building-integrated photovoltaics (BIPV) and building-applied photovoltaics (BAPV). For the BIPV system, the PV system replaces the traditional building envelopes, such as windows, roofs, walls and itself acts as a building envelope, whereas for the BAPV system, PVs are applied or attached to the building walls or roofs. Both BAPV and BIPV works as an onsite green power generation, reducing the transmission losses, and improving the building's overall performance.

In this paper, various technologies involving BIPV and BAPV approaches have been discussed and their potential application for Indian context has been critically analyzed in detail. Moreover, solar potential and PV power electricity market in India are also discussed.

\section{PV Technologies for BIPV/BAPV}

Presently PV technologies include first-generation opaque silicon type, second-generation transparent or semitransparent thin film and third or emerging types [12]. Until now, the first generations are employed for BIPV and BAPV applications, whereas second and third generations are primarily considered for BIPV application.

Crystalline silicon (c-Si) PV cells are the most widely used and predominant technology in the market due to their mature and long-term durability. Monocrystalline PV cells are made from a single crystal, developed using the Czochralski process with the best-reported efficiency of nearly $22 \%$. Polycrystalline solar cells are developed by melting several fragments of silicon together to form a wafer. Typical efficiency is in the range of $14-18 \%$ for polycrystalline PV cells, which is less efficient than the monocrystalline counterparts, since electrons have less freedom of movement due 
to grain boundaries of many crystals in each cell. However various anti-reflective coatings can be applied onto the surface to change the color of the PV cells. Presently colored silicon PV is also under investigation [13,14]. The major constraints of crystalline silicon PV cells are power losses due to the shading and at elevated temperature [15-22].

Thin films include (i) amorphous silicon (a-Si) (ii) Copper - Indium Selenide (CIS) or Copper-Indium-Gallium- Selenide (CIGS), (iii) Cadmium-Telluride (CdTe). The thickness of the film could be a few nanometers to micrometers. These technologies have meager efficiencies in comparison to c-Si, typically $11-12 \%$. However, they have several advantages such as (a) less loss in performance under overcast cloudy climatic conditions and partial shading from obstacles $[23,24](b)$ employ lower semiconductor material and hence lower production cost (c) manufacture of transparent or translucent modules using laser scribing [25-27]. Amorphous silicon is the non-crystalline form of silicon, with atoms disoriented in a random network structure. The major advantage of it is being able to be deposited as thin films on to a moldable substrate like plastic at less than $300{ }^{\circ} \mathrm{C}$ of manufacturing temperature. Moreover, its absorptivity is higher ( 40 times) and needs only $1 \%$ (about $1 \mu \mathrm{m}$ ) of material of crystalline silicon, which results in lower making cost/unit-area. Due to its flexible nature, it can be molded into any suitable complex shape for building integration. Although it has high efficiency in comparison to other thin-film technologies, it suffers from degradation due to hydrogenation (Staebler-Wronski effect) [28-33]. Cadmium telluride (CdTe) is a single-junction solar cell having $1.45 \mathrm{eV}$ bandgap energy. It is a direct bandgap semiconductor nearly ideal for optimal conversion of solar radiation into electricity. An efficiency exceeding $20 \%$ has been reported CdTe PV. The major limitations of CdTe cells are its instability and toxicity of cadmium which makes it less suitable for PV application. Copper Indium Gallium Diselenide (CIS) is a polycrystalline compound consisting of copper, indium, gallium, sulphur and selenide elements, with the highest reported conversion efficiency of about $25 \%$ in combination with perovskites [34] CIS has high light absorptivity and $0.5 \mu \mathrm{m}$ of CIS can absorb $90 \%$ of the solar spectrum [35]. Similar to other thin-film technology, CIGSs are semi-transparent and flexible.

Emerging third generations are gaining importance due to their low fabrication cost, and transparent and semitransparent makes them a potential candidate for aesthetic building integration. Organic photovoltaics uses organic polymer as the light-absorbing layer. Organic PVs are lightweight, and flexible which allows them to be applied in building as a BIPV system [36-38]. O'Regan and Gratzel carried out seminal work on dye-sensitized solar cells (DSSC) [39]. Since its inception, extensive research was carried out to improve the efficiency and stability of DSSC. DSSCs are considered for BIPV application due to its simpler and low-cost fabrication process, flexible, have potential to operate at diffuse solar radiation [40,41]. Colored and semi-transparent windows are popular for BIPV application $[42,43]$. However, factors inhibiting to its commercialization are long term- stability and durability. Table 1 listed the advantage and disadvantages of various PV technologies. Recently, Perovskite PV gained attention due to its efficiency improvement in 10 years. However, they are mostly operated and fabricated at inert atmospheric condition. Tunable transparency [44], and low temperature fabrication [45] makes it fascinating to researcher for BIPV application [46,47].

Table 1. Advantages of disadvantages of various solar cells.

\begin{tabular}{|l|ll|l|}
\hline \multicolumn{1}{|c|}{ Solar cell } & \multicolumn{1}{|c|}{ Advantages } & \multicolumn{1}{c|}{ Disadvantages } \\
\hline Monocrystalline silicon solar cells & $\bullet 17,48,49]$ & $\begin{array}{l}\text { Matured PV technologies. } \\
\text { Highly durable. } \\
\text { Suitable for } \\
\text { BAPV application. }\end{array}$ & $\begin{array}{l}\text { There is a lot of waste } \\
\text { material when silicon is } \\
\text { removed during processing. } \\
\text { At high temperature, } \\
\text { performance degrades. } \\
\text { Opaque in nature, hence less } \\
\text { suitable for artistic } \\
\text { BIPV application. }\end{array}$ \\
\hline
\end{tabular}


Table 1. Cont.

\begin{tabular}{|c|c|c|}
\hline \begin{tabular}{|l} 
Solar cell \\
\end{tabular} & Advantages & Disadvantages \\
\hline $\begin{array}{l}\text { Polycrystalline silicon solar cells } \\
\text { [50-52] }\end{array}$ & $\begin{array}{l}\text { - The production process is } \\
\text { simpler than the } \\
\text { monocrystalline cells. } \\
\text { - Highly durable. }\end{array}$ & $\begin{array}{l}\text { Due to low level of silicon } \\
\text { purity, performance is only } \\
\text { around } 13-16 \% \text {. }\end{array}$ \\
\hline $\begin{array}{l}\text { Amorphous silicon solar cells } \\
\text { [53-55] }\end{array}$ & $\begin{array}{l}\text { - Low manufacturing costs. } \\
\text { - The cell can be produced in } \\
\text { various shapes. } \\
\text { At high temperature, } \\
\text { performance degradation is } \\
\text { lower than crystalline silicon. }\end{array}$ & $\begin{array}{l}\text { - The efficiency is typically } \\
6-8 \% \text {. } \\
\text { - They have shorter lifetime } \\
\text { compared to other solar cells. } \\
\text { - Required twice, the space to } \\
\text { get same PV power than that } \\
\text { of crystalline silicon. }\end{array}$ \\
\hline CdTe solar cells [56-61] & $\begin{array}{l}\text { - Cadmium is abundant. } \\
\text { - The manufacturing process } \\
\text { is simple. } \\
\text { - It can absorb light of } \\
\text { shorter wavelength. }\end{array}$ & $\begin{array}{l}\text { The efficiency operates in the } \\
\text { range } 9-11 \% \text {. } \\
\text { - Tellurium is not abundant. } \\
\text { - Cadmium telluride is toxic } \\
\text { and not } \\
\text { environmentally benign. }\end{array}$ \\
\hline CIGS solar cells $[35,52,62-67]$ & $\begin{array}{l}\text { - CIGS solar cells use lower } \\
\text { levels of cadmium, in the } \\
\text { form of cadmium sulphide. } \\
\text { CIGS solar cell substrates are } \\
\text { more versatile in comparison } \\
\text { with c-Si. } \\
\text { CIGS solar panels show } \\
\text { better resistance to heat } \\
\text { compared to silicon } \\
\text { solar cells. }\end{array}$ & $\begin{array}{l}\text { - The efficiency ranges in } \\
\text { between } 12-14 \% \text {. } \\
\text { - High fabrication and } \\
\text { production costs. }\end{array}$ \\
\hline Organic solar cells [36-38] & $\begin{array}{l}\text { The PV modules are low } \\
\text { weight and flexible. } \\
\text { Lower production costs than } \\
\text { traditional inorganic } \\
\text { technologies, such as silicon } \\
\text { solar cells. }\end{array}$ & $\begin{array}{l}\text { - } \quad \text { Lifetime is short. } \\
\text { - Very low efficiency around } \\
4-5 \% \text {. }\end{array}$ \\
\hline DSSC [68-70] & $\begin{array}{l}\text { - It consists of low-cost } \\
\text { materials easy fabrication. } \\
\text { It works even in low light } \\
\text { conditions such as the } \\
\text { cloudy weather. } \\
\text { - Tunable transparency is } \\
\text { possible by tuning the } \\
\text { thickness and dye. } \\
\text { Use of flexible substrate } \\
\text { makes it flexible and suitable } \\
\text { for BIPV. }\end{array}$ & $\begin{array}{l}\text { - } \quad \text { Low efficiency around } 12 \% \text {. } \\
\text { - The liquid electrolyte has } \\
\text { temperature } \\
\text { stability problems. } \\
\text { - } \quad \text { The liquid will quickly } \\
\text { dry up. } \\
\text { - Long term stability } \\
\text { is questionable. }\end{array}$ \\
\hline
\end{tabular}


Table 1. Cont.

\begin{tabular}{|c|c|c|}
\hline \begin{tabular}{|l} 
Solar cell \\
\end{tabular} & Advantages & Disadvantages \\
\hline Perovskite solar cells [71-73] & $\begin{array}{l}\text { - Perovskite uses smaller } \\
\text { quantity of material to absorb } \\
\text { the equivalent amount of } \\
\text { light in comparison to c-Si. } \\
\text { Perovskite materials, like } \\
\text { methylammonium lead } \\
\text { halides are cheap and easy } \\
\text { to produce. } \\
\text { - } \quad \\
\text { Semi-transparent/transparent } \\
\text { cells are possible, which } \\
\text { makes it suitable for aesthetic } \\
\text { building application. }\end{array}$ & $\begin{array}{l}\text { - Not stable at } \\
\text { ambient condition. } \\
\text { - Not fully } \\
\text { matured technology. } \\
\text { - Thermal performance of this } \\
\text { technology is not well. }\end{array}$ \\
\hline
\end{tabular}

\section{Building Integrated and Applied Photovoltaic (BIPV/BAPV) Technologies}

BAPVs are an addition to the traditional or new PV system, on an existing or new building whereas BIPVs replace the existing traditional building envelope, such as window, roof, and wall [74]. Hence, BIPV has a greater impact on the building's indoor environment. BIPVs are often transparent or semi-transparent by nature, which allows incident daylight and solar heat to pass through, thereby directly modifying the indoor ambiances. Additionally, it also has a variety of capabilities like control solar heat gain or loss, daylight glare and offset the window, roof or wall material cost [75]. On the other hand, BAPVs have no such contribution to the building environment other than the production of green power. Currently, available BIPV products include BIPV tile, foil and glazing [76,77]. BIPV foils and tiles are primarily applied on the roof while BIPV glazings are mostly employed for vertical semi-transparent and transparent windows, façade and wall applications. Presently, $80 \%$ of the BIPV market contributes to rooftop-mounted and only $20 \%$ of it is in accord for façade-mounted [2,78-82]. Generally, rooftops, standing without any hindrance from nearby tall buildings or trees, are the ideal solutions to harvest the best energy when pitched at certain elevation angles. BIPV foil products are best suited for building applications due to their flexibility and light-weight properties. PV cells for BIPV products are mostly thin films, which possess low power generation due to the high electrical resistance of the thin film. However, due to a low temperature coefficient of thin-film BIPV foil, power degradation is comparatively less at high temperatures to silicon types. Alwitra $\mathrm{GmbH}$ and $\mathrm{Co}$, which uses amorphous silicon cells and Uni-Solar cells are the present manufacturers of BIPV foil. Next, BIPV tiles are most prominently used as roof integration, which includes covering the entire roof or selected part of the roof with BIPV tiles. Some of these tiles also appear to be similar to that of a ceramic curved tile, which might be aesthetically pleasing but are not effective in terms of power generation, due to its curved surface area [76,77]. SRS Energy, Solar Century, Luma solar, Suntegra and, Sunflare Tesla are few of the present BIPV tile manufacturers.

Figure 1 shows the presently available BIPV and BAPV products. BIPV windows are one of the most fascinating applications, responsible for maintaining visual comfort between the external world and building interior, modulating available daylight and heat. Crystalline silicon [83,84], amorphous silicon [85-88], CdTe [89,90], DSSC [91,92] and perovskite [44] are the few materials, which when intensely investigated for BIPV window applications (shown in Figure 2), have found impressive possibilities towards building integration. 


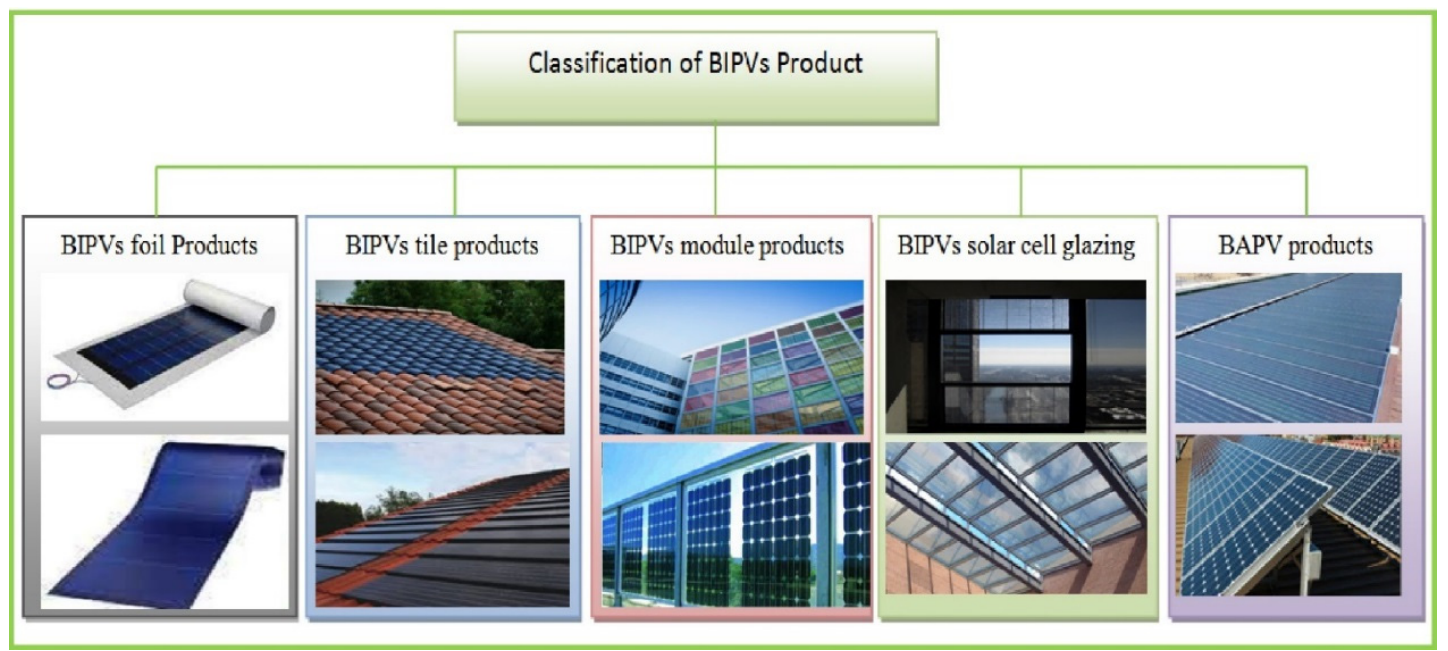

Figure 1. Major BIPV and BAPV products [79].

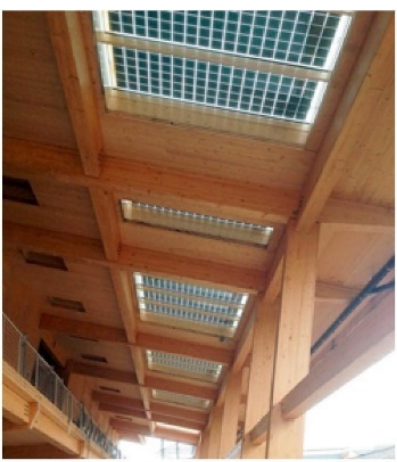

(a) $\mathrm{c}-\mathrm{Si}$

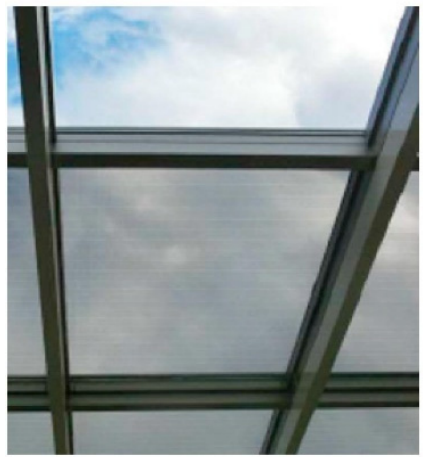

(d) $\mathrm{CdTe}$

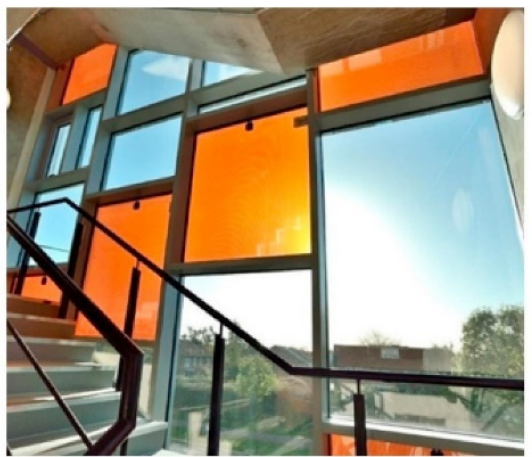

(b) a-Si

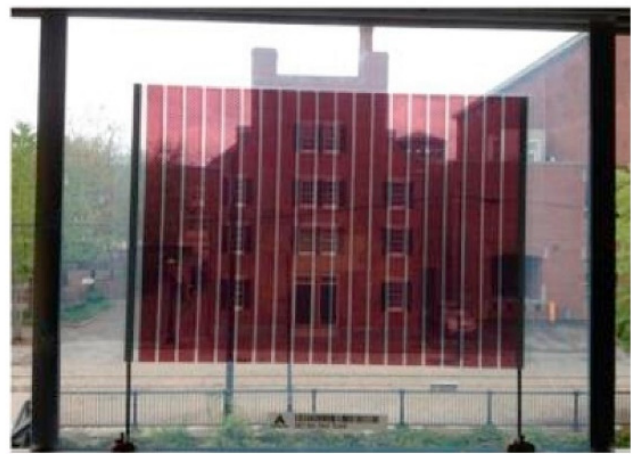

(e) OPV

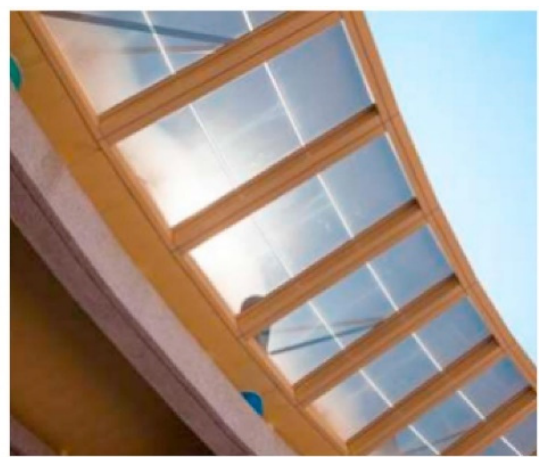

(c) $\mathrm{a}-\mathrm{Si} / \mu \mathrm{c}-\mathrm{Si}$

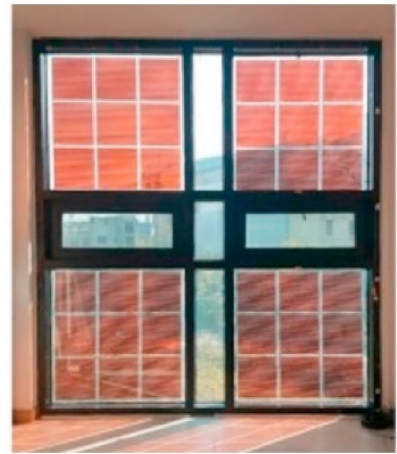

(f) DSSC

Figure 2. Window integrated with different types of PV cell materials [93].

Concentrator-based BIPV windows are also very attractive for less energy-hungry building integration. Low concentrating compound parabolic concentrator (CPC) [94] and luminescent solar concentrators (LSC) [95] are now dominating the major building-integrated concentrating photovoltaic research activity. Low concentrators are static which reduces the cost of the expensive solar tracker. The thermal effect is lower than a high concentrator, due to a low concentrator on PV cells, which reduces the necessity of a cooling system and makes a low concentrator a suitable candidate for building's window and façade application [96-98]. For northern latitude location, diffuse solar radiations are higher, CPC and LSC both work efficiently. Concentrating PV came into a scenario to reduce the usage of the costly silicon material by replacing low-cost material, which concentrates a 
higher amount of incident solar light on a lesser PV material [99]. For crystalline silicon-CPC-based BIPV window, regular distribution of spacing between PV cells offer semi-transparency (silicon solar cells are opaque), as shown in Figure 3. Different geometries of CPCs were investigated for BIPV window and façade application [100-103]. Recently, the performance of DSSC and perovskite solar cells was also investigated, using low concentrating CPC, which enhanced the PV performance than non-concentrating counterpart $[104,105]$.

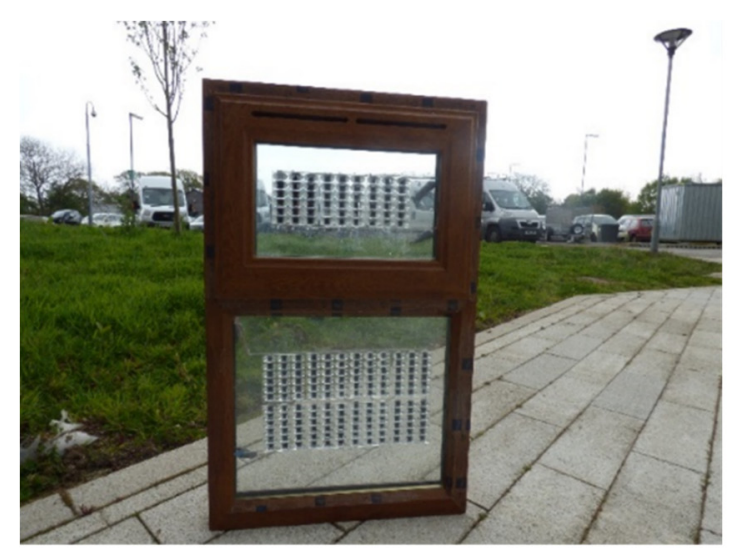

(a)

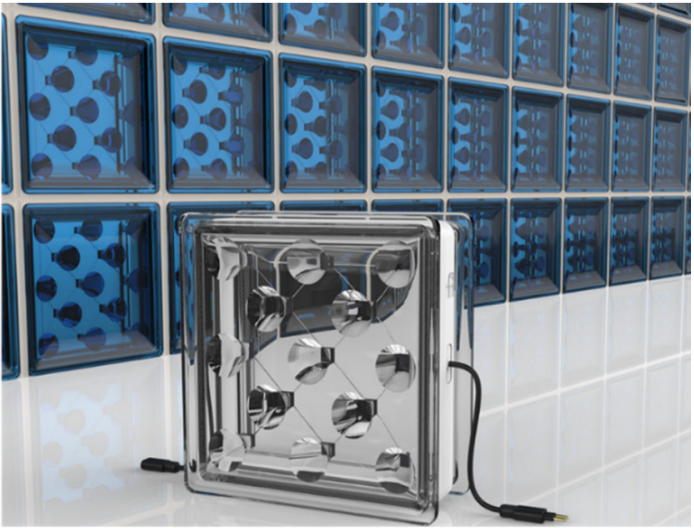

(b)

Figure 3. (a) CPC based BIPV, (b) Semi-transparent building blocks using CPC-silicon PV (image courtesy Build Solar).

A typical LSC consists of a glass or plastic-based square/rectangular-shaped waveguide luminophores, which absorbs a short-wavelength photon and convert them into long-wavelength. Further, due to total internal reflection, these photons finally reach the PV cells attached at the edge of the waveguide [106-110], as shown in Figure 4. The advantage of LSC-BIPV system is that the PV cells are placed at the edge, which does not create an obstacle for viewing. Also, this waveguide plate can be made semi-transparent to fully-transparent or different colors, which is aesthetic for building application and suitable for building window integration [111-114]. Promising results, using LSC-thin film integration, was also reported by [115]. LSC does not possess any thermal effect on PV cells, which is an added advantage over low concentrating CPC.
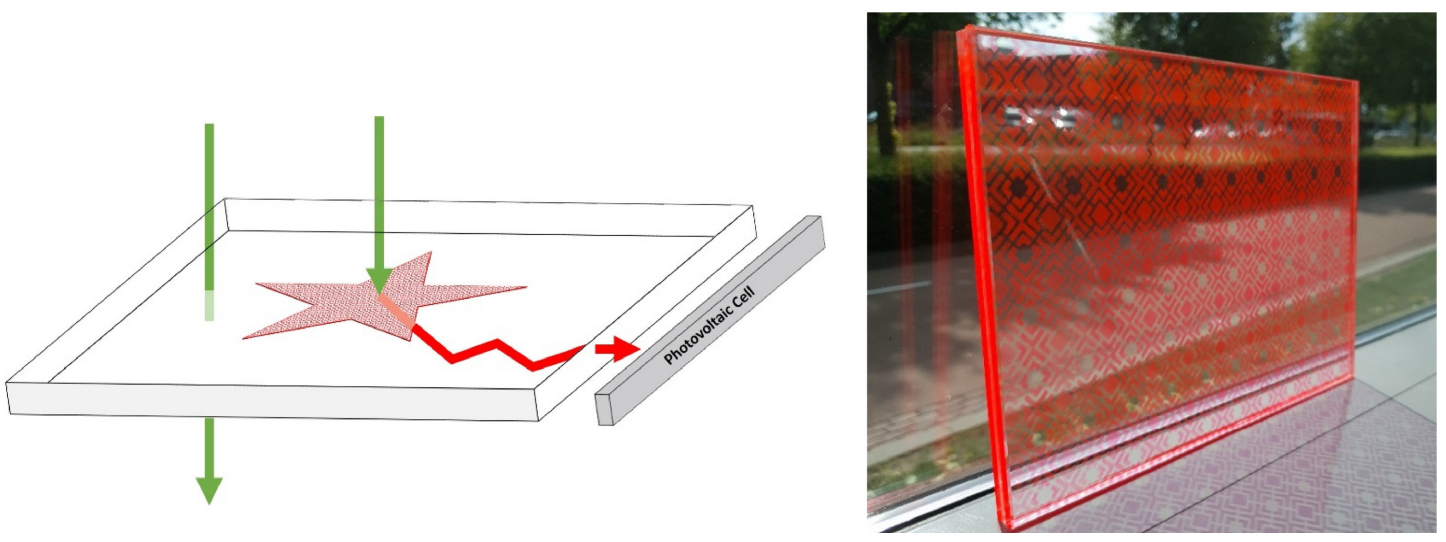

Figure 4. Working principle of inkjet-printed luminescent solar concentrator and photograph of a printed A4 sized luminescent solar concentrator [109].

The performance degradation of both BIPV and BAPV is possible at higher ambient temperature and exposure to higher incident radiation, which increases the PV cell's temperature. Crystalline silicon and thin-film both work, with poor efficiency, at higher PV cell temperature. Thermal regulation BAPV 
system is possible by employing forced water flow, forced airflow or phase change material (PCM) at the back of the system $[116,117]$. At the back of the BPAV system, copper pipes are integrated to flow the air [118-120] or water [121,122]. This typical BAPV is also known as BAPV-thermal (BAPV/T) water or air collector, where water or air will extract the additional heat energy from the PV system and allow PV system to operate efficiently. Hot air or water can be used by building purposes [123]. Notably, researchers often misuse the BIPV term [121,122,124-130]. As BIPV is attached as a building envelope, natural airflow and PCM are the only two available and investigated options to diminish the elevated PV cell temperature [131-133]. The inclusion of collector to BIPV was forced to compromise with buildings aesthetic. For a system which is BAPV/T system is most often referred to as BIPV/T in the articles. Hence, care should be taken when referring to a PV/T system as BAPV/T or BIPV/T. A typical BAPV/T with a water flow system is shown in Figure 5. Details of BIPV and BAPV are listed in Table 2.

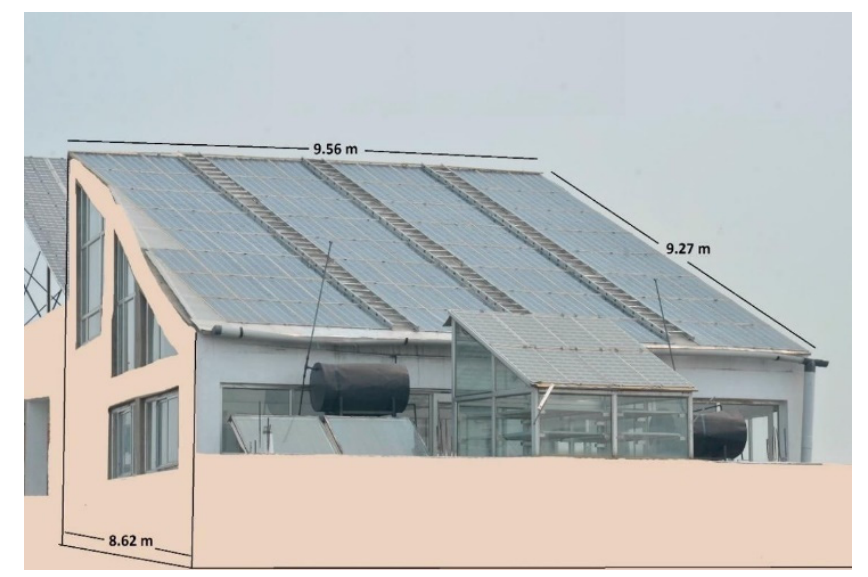

Figure 5. BAPV/T system installed at Sodha BERS complex, Varanasi (25.33 $\left.{ }^{\circ} \mathrm{N}, 82.99^{\circ} \mathrm{E}\right)$ [134].

Table 2. Details of different BIPV and BAPV products.

\begin{tabular}{|l|l|l|}
\hline \multicolumn{1}{|c|}{ Product } & \multicolumn{1}{|c|}{ Type of Cell } & \multicolumn{1}{c|}{ Particular Purpose } \\
\hline BIPV window & $\begin{array}{l}\text { 1st generation } \\
\text { 2nd generation } \\
\text { 3rd generation }\end{array}$ & $\begin{array}{l}\text { Control daylight, solar heat } \\
\text { Aesthetic application } \\
\text { Power generation gets } \\
\text { lower priority }\end{array}$ \\
\hline BIPV foil/tiles & $\begin{array}{l}\text { 2nd generation (mostly available) } \\
\text { 3rd generation (suitable but } \\
\text { stability should be improved }\end{array}$ & $\begin{array}{l}\text { Works as building shading from } \\
\text { the harsh external environment } \\
\text { Power generation gets } \\
\text { lower priority }\end{array}$ \\
\hline Spaced type concentrating BIPV & $\begin{array}{l}\text { 1st generation (experimentally } \\
\text { validated/commercial product } \\
\text { is available) } \\
\text { 2nd generation (no report) } \\
\text { 3rd generation (experimentally } \\
\text { explored in the lab) }\end{array}$ & $\begin{array}{l}\text { Improve the power generation } \\
\text { Reduce the cost of the system } \\
\text { Spaced type allow daylight } \\
\text { suitable for passive house } \\
\text { application/zero } \\
\text { energy application }\end{array}$ \\
\hline BAPV/T & $\begin{array}{l}\text { 1st generation } \\
\text { 2nd generation }\end{array}$ & \begin{tabular}{l} 
Suitable for rooftop application \\
\hline
\end{tabular} \\
\hline
\end{tabular}

\section{Potential of BIPV/BAPV in India}

India lies between $68^{\circ} 7^{\prime}$ to $97^{\circ} 25^{\prime}$ east longitude and $8^{\circ} 4^{\prime}$ to $37^{\circ} 6^{\prime}$ north latitude, has 2.9 million $\mathrm{Km}^{2}$ of landmass, and is the seventh largest country in the world. It is in the tropical region and receives maximum solar radiation in summer, and experiences about 300 sunny clear days in a year. Ambient 
conditions vary from $45^{\circ} \mathrm{C}$ in summer while $4{ }^{\circ} \mathrm{C}$ in winter and has a hot-dry, warm-humid, composite, temperate, and cold climatic zones [135]. India's rich solar radiation profile shows $4.5-5.0 \mathrm{KWh} / \mathrm{m}^{2} / \mathrm{Day}$ of annual average direct normal irradiance in most of the Indian states and around $5.0-5.5 \mathrm{KWh} / \mathrm{m}^{2} /$ Day average global horizontal irradiance $[136,137]$. This makes India one of the most potential candidates to contribute to PV power generation. Figure 6 shows the solar radiation intensity throughout India. India's projected electricity demand in 2047 is expected to be $5518 \mathrm{TWh}$. India's present energy demand is supplied by $70 \%$ of imported crude oil and coal. Indian thermal power plants, that are run by coal, are the most inefficient ones. Hence, in order to become an energy-secured country and dependent from oil-import, India should use its solar PV power potential. Although, India has a higher solar radiation, being a developing country, PV power generation faces issues, including high initial installation cost of PV power generation, the lack of suitable storage devices or unavailable during an instant power supply demand. Backup power supply from fossil fuel-generated kerosene oil lamps, diesel generators, etc. are still low cost in India [138]. However, this fossil fuel generated power emits considerable amount of green house gas ( GHG). India is committed to lowering its GHG to $30-33 \%$ by 2030, compared to 2005 level.

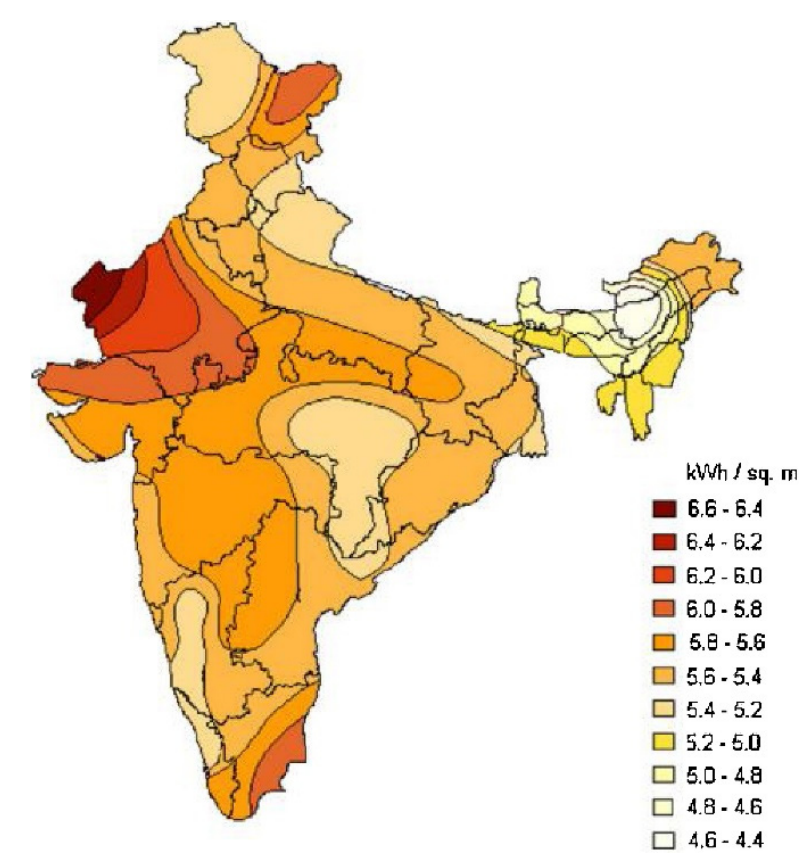

Figure 6. Physical map Indian solar radiation [139].

Interestingly, energy generation from PV devices was in discussion in India since 1960. However, progress was limited until 2010 [140,141]. The first significant move was taken in 2010 to priorities the PV power generation through the National Action Plan on Climate Change, by launching the JNSSM scheme [142]. In 2010, the total installed capacity from PV was only 39.6 MW. After Prime Minister Narendra Modi came into power, India's 2022 target changed from 20 GW to $100 \mathrm{GW}$, which included grid-connected projects, off-grid projects, and solar parks. It was also fixed that out of $100 \mathrm{GW}$, rooftop PV should produce 40 GW by 2022 [143]. Under the JNSSM mission, grid-connected rooftops and small solar power plant programs have been launched to obtain the $40 \mathrm{GW}$ rooftop power generation. The minimum and maximum limit of installing PV power capacity are to $1 \mathrm{kWp}$, and $500 \mathrm{kWp}$, respectively $[139,144]$. India has 29 states and 7 union territory out of which Madhya Pradesh, Gujarat Ladakh, Andhra Pradesh, Maharashtra, and Rajasthan receive the maximum amount of average annual solar radiation, as compared to other states of India. Gujarat is the first Indian state which implemented a solar policy in the year 2009, well before the initiation of JNNSM. Rajasthan started its solar mission in 2011 to meet the national target. Karnataka started its solar mission for the 
period of 2014 to 2021. Madhya-Pradesh started its solar policy in 2012 and provided the incentives and benefits to the Private Sector to encourage the PV installation [145]. To initiate the government target, several commercial investors came in front. Cleanmax solar had invested Rs 600 crores to set up a $150 \mathrm{MW}$ solar farm in Sirsa District, Haryana (near to New Delhi, 29.05 $\mathrm{N}, 76.08^{\circ} \mathrm{E}$ ) on a stretch of 600 acres of land. Bharathi Cement had commissioned a 10 MW solar power plant in the manufacturing facility, located at Kadapa in Andhra Pradesh $\left(14.46^{\circ} \mathrm{N}, 78.82^{\circ} \mathrm{E}\right)$. The plant is expected to generate 1.6 crore units of electric power annually, and help to reduce Bharathi's overall energy costs by reducing its dependence on thermal power. Maruti Suzuki India had planned to invest Rs 24 crore (\$3366k) to set up a $5 \mathrm{MW}$ solar power plant at its Gurugram $\left(28.45^{\circ} \mathrm{N}, 77.02^{\circ} \mathrm{E}\right)$ facility. The plant would help to lower $\mathrm{CO}_{2}$ emissions by 5,390 tonnes annually in 25 years. ReNew Power had commissioned $300 \mathrm{MW}$ solar plant at Pavagada Solar Park in Tumkur district in Karnataka (13.37 $\mathrm{N}, 76.64^{\circ} \mathrm{E}$ ). The solar power plant could reduce 0.6 million tonnes of $\mathrm{CO}_{2}$ emission per year. The plant uses high efficiency Mono PERC solar modules and is based on seasonal tilt technology with string invertors. However, solar power plants are practically is not feasible for urban areas where large amount of space is required. India's population growth and rapid urbanization land availability for solar plants will be a complicated issue. Hence, solar rooftops should be given higher priority. Some of the major PV installations include Braboune stadium, Mumbai, which is the world's largest solar rooftop with capacity of $820.8 \mathrm{kWp}$, as shown in Figure 7a. Another major installation is carport at Cochin International Airport, which is India's largest carport solarized by Tata Power Solar. The plant is $2.67 \mathrm{MW}$, and is spread across an area of $20289.9 \mathrm{~m}^{2}$, which offsets 1868 tons of $\mathrm{CO}_{2}$ as shown in Figure $7 \mathrm{~b}$.

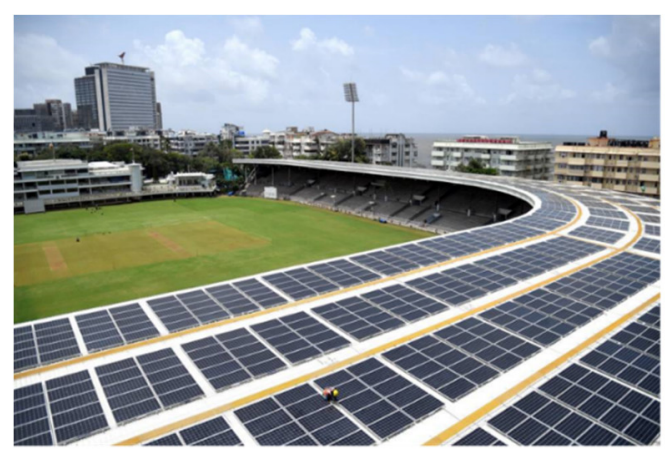

(a)

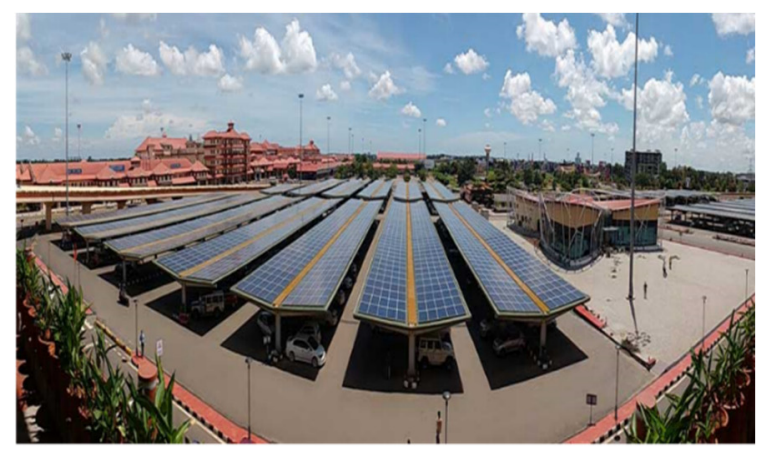

(b)

Figure 7. (a) World's largest solar rooftop with a capacity of $820.8 \mathrm{kWp}$ installed on Braboune stadium, at Cricket Club of India, in Mumbai $\left(18.93^{\circ} \mathrm{N}, 72.82^{\circ} \mathrm{E}\right)(\mathbf{b})$ India's largest solar carport $2.67 \mathrm{Mw}$ at Cochin International Airport (Cial) $\left(10.15^{\circ} \mathrm{N}, 76.39^{\circ} \mathrm{E}\right)$.

Although, in India, 83.3 crore reside in a rural area out of 121 crores, urbanization is occuring at a rapid pace. Every minute, 30 Indians move from a rural area to a city, seeking better-paying jobs. Population and economic growth have fostered urbanization in the country and the number of urban towns and cities has drastically increased [146,147]. By the end of 2030, 590 million Indians will be in city for which new buildings are required. It is expected that five-fold built space will be in 2030 than 2005 level in India, of which 60\% will be air-conditioned space. Maintaining similar conditions, Indian's building can consume energy and emits GHG with a 700\% increment by 2050, compared to 2005 levels [135]. Presently building consumes 30\% of electricity in India [148]. The reduction of building energy enhances the demand for sustainable building, which will perform as low energy or less energy-hungry building by trim down the HVAC load demand. To attain such a building, envelopes need to be energy efficient and responsive to an outdoor conundrum. To assess the performance of the buildings, The Energy and Resource Institute of India (TERI) and MNRE has created Green Rating for Integrated Habitat Assessment (GRIHA), and the Leadership in Energy and Environmental Design (LEED) rating tools to help curtail the substantial resources consumed by the building industry, and 
to reduce the overall environmental impact within tolerable limits. GRIHA evaluates the ecological performance of the building comprehensively by controlling energy consumption, reducing carbon dioxide gas emissions and reinforce the use of inexhaustible and processable sources to the best possible extent $[149,150]$. MNRE also encourages now passive building which will use solar energy by the suitable orientation of building for daylighting, heating and cooling load demand [151].

BIPV and BAPV both can contribute a considerable amount of energy and improve the building's indoor environment in India [152,153]. However, the dearth of BIPV experts and BIPV marketing professionals, limited in-house consumption data, dearth of ability in planning, commissioning, operation, and maintenance of solar PV/BIPV projects, inadequate training and capacity building, not enough available information about BIPV for policy-making and mobilizing civil society are the barrier for Indian BIPV/BAPV market [81,82]. Another major barrier for widespread PV in India is the lack of resources of raw materials for PV manufacturing. BIPV technology, which is mainly thin-film-based, did not have much uptake in India due to the same reason. For crystalline silicon, India depends on import of the silicon wafer. Currently, in India, the thin-film PV industries are run by US-based First Solar (22\% share), Canadian Solar (6\% share) and $6 \%$ share of Trina Solar Chinese manufacture $(6 \%)$. India also cannot support CdTe production as India's copper refining industry size is not big enough and upgradation is required to enhance tellurium recovery rates from the copper refining process [154]. The Indian developer, Vikram Solar, has a 3.5\% share followed by Moser Baer, Tata Power Solar and Lanco [155]. China controls over 97\% of rare earth material which makes them capable to control the price of thin-film [155]. Poor performance of thin-film PV system compared to silicon PV system creates a negative impact on thin-film BIPV system. Thin film degradation occurs in higher rate than crystalline PV over 25 years. Also, thin-film PV cells possess micro-cracks after few years of operation, due to the temperature gradient differences between bottom and top, which cause additional cost of replacement. In India, utilization of BIPV and BAPV is still not fully well established and primarily most of the major integration types are BAPV. Solar rooftop PV application which is BAPV technologies are predominant in India. According to census 2011, in India, there are 331 million households, with urban settlement area of $77,370 \mathrm{~km}^{2}$, which can be a huge potential of $124 \mathrm{GW}$ for rooftop BAPV to satisfy $40 \mathrm{GW}$ rooftop PV power generation target by 2022. Rooftop PV installations grew at robust pace adding 1,836 MW in the financial year 2018-2019, with a total becoming $10 \mathrm{GW}$. Figure 8 a shows the spaced type semitransparent crystalline solar BIPV module integrated on the rooftop having installed capacity of $1.68 \mathrm{kWp}$. Each module had dimensions of $1963 \mathrm{~mm} \times 0.987 \mathrm{~mm} \times 40 \mathrm{~mm}$ covered with $36 \mathrm{c}$-Si panels with a transparent area of $49 \%$ and rated power of $150 \mathrm{~W}$. Figure $8 \mathrm{~b}$ shows the India's first zero energy building, which was constructed in 2014. PV panels occupy $4600 \mathrm{~m}^{2}$ area and annual energy generation cost is 14 lakh (\$19k) Unit kWh, while the cost of installation was Rs 18 crore (\$2533k). Coal India Limited's Corporate Headquarters at Rajarhat in Kolkata $\left(22.57^{\circ} \mathrm{N}, 88.37^{\circ} \mathrm{E}\right)$ installed $632 \mathrm{PV}$ panels with total capacity of $140 \mathrm{~kW}$. The solar energy powers the uninterrupted power supply for desktops, emergency lighting systems and the landscape lighting of CIL's corporate office. Tata BP Solar has implemented $30 \mathrm{kWp}(\$ 250,000)$ BAPV system in Samudra Institute of Maritime Studies in Pune $\left(18.52^{\circ} \mathrm{N}, 73.85^{\circ} \mathrm{E}\right)$. Moser Baer has installed a $1.8 \mathrm{kWp}$ BIPV exterior façade of Jubilee shopping complex in Hyderabad $\left(17.38^{\circ} \mathrm{N}, 78.48^{\circ} \mathrm{E}\right)$ to meet power requirements in shopping complexes. The government buildings in India are also encouraged to use solar energy in an aesthetic approach by using BIPV/BAPV technology. The government is also focused on increasing the roof top systems and streamlining policy implementation processes. In 2015, Novus green installed a 1MW BAPV system (4000 PV system each had $250 \mathrm{Wp}$ ) at the rooftop of IIT Delhi. Energy Efficiency Services (EESL) had planned to invest INR 800 crore for rooftop solar in Maharashtra across 5000 state-owned buildings to install $200 \mathrm{MW}$ grid-connected systems. EESL estimates that about 100 million units would be saved per year by replacing energy-inefficient ceiling fans (6 lakh), LED bulbs (11 lakh) and air-conditioners (7000) along with streetlights $(14,000)$ and retrofitting 3000 buildings. 


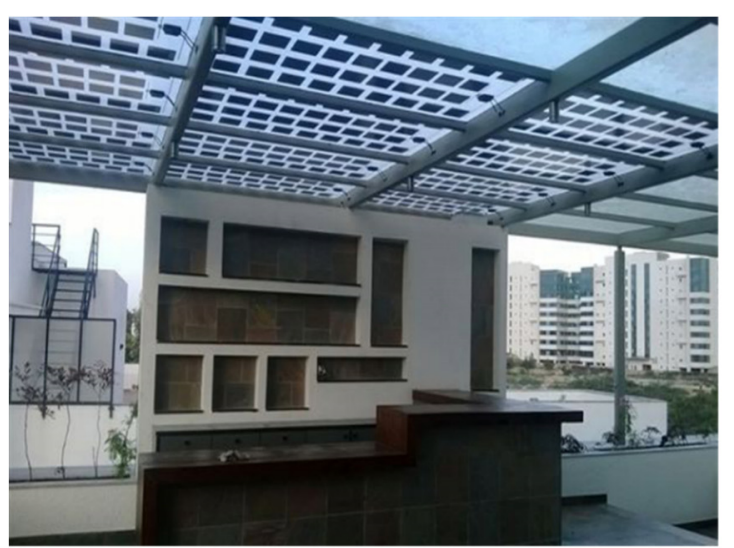

(a)

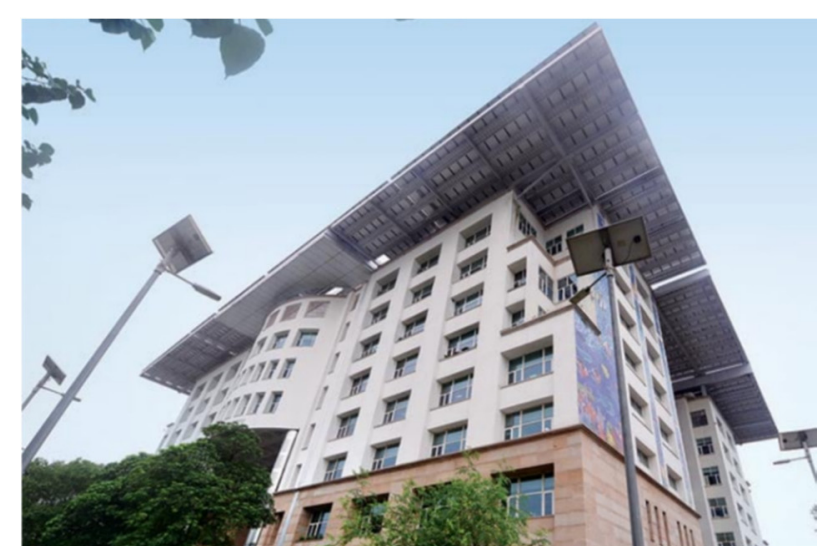

(b)

Figure 8. (a) Spaced type crystalline silicon solar-based BIPV roof for daylighting application (Source: HHV solar, Bangalore, India), (b) BAPV system in Indira Paryavaran Bhawan India (Image source: BT).

Another barrier in India for poor BIPV/BAPV - standalone system is the unorganized Indian electricity market. The PV power generation sector includes three different customers. The first customer state distribution companies (DISCOMs) who have renewable purchase obligations (RPO) to buy PV power and meet 10.5\% PV electricity generated, second is the rooftop PV consumers (RPVCs) and third is large buyers of power who are also known as open access consumers (OACs) [156]. Under open access $(\mathrm{OA})$, consumers are capable of buying electricity from producers who generate electricity independently. Indian rail started exploring PV power from OA. Developers feel that RPO is not same for all state as State Electricity Regulatory Commissions (SERCs) has different benchmark for each state. PV power electricity price varies from INR 7.5 to INR18.5/kWh. In 2010, Central Electricity Regularity Commission (CERC) has implemented the PV/BIPV feed-in tariff of INR 17.9/kWh [157]. In India, the coal power electricity price is about INR $5.5 / \mathrm{kW} \mathrm{h}$, while the PV power price is about INR6.5/ $\mathrm{kW} \mathrm{h}$. Hence, project developers are compelled to offer discounts [158]. Thus, DISCOMs are failing to comply with RPO requirements, due to their poor financial health and lower solar tariff support. Hence, they prefer to wait for buying low price PV electricity. DISCOMs also argued that BIPV/BAPV based standalone systems increase their financial burden as RPV customers prefer to buy grid electricity over BIPV/BAPV power due to intermittency. Intermittent PV power generation is also an issue for the promotion of OA [159]. To rectify this issue, energy banking can be created where DISCOM will facilitate OA transactions through electricity banking, between an independent power producer and OAC. DISCOM can generate less power whenever an independent power producer generates a higher amount of power than the OAC's demand, in order to use surplus PV power and generate when PV generation is reduced and shortfalls arise $[159,160]$. The presence of multiple electricity regulatory boards like MNRE (Ministry of New and Renewable Energy), CERC (Central Electricity Regulatory Commission), SERC (Ministry of Power and State Electricity Regulatory Commission) also make the legal process a cumbersome task [161].

By the end of Sep 2019, India's cumulative installed solar capacity stood at $33.8 \mathrm{GW}$, of which $88 \%$ are PV plants and $12 \%$ rooftop installations. Ambiguity in incentive implementation, non-availability of storage systems incentives, lack of consumer awareness and research studies are the reason behind this sluggish movement for rooftop PV application in India [162]. Dust accumulation, which reduces PV power generation, should also be taken care of as air quality in India can pose a negative impact [163-165].

\section{Perspective and Discussion}

It is evident that in India, solar PV power generation got heads up after the year of 2015. Rooftop installation got priority however it included rooftop of any large construction whether it is a building 
(residential/commercial) or other area, such as a stadium or car park. Hence, it is difficult to differentiate or estimate the installed percentage for only rooftop building. Until now, power generation from PV has only just become a higher priority than aesthetic application. In India, BAPV system is prevalent and they are wrongly termed as BIPV systems. Actual, BIPV technology is not particularly popular in India, which could be the reason for lack of government plan and policy, and awareness to the public. BIPV window tiles or foil technology is not popular in India. Thermal regulation of BAPVT in the name of BIPVT is available in India [129]. The primary goal of this work to enhance PV power generation, rather than reducing the building cooling load demand. Improvements in the building environment, using BIPV, should be in government policy. Concentrating PV in India is mainly higher in concentrators [166]. To the best of our knowledge, no work has been reported on a low concentrator using LSC- or CPC-based BIPV/BAPV in India. To meet the GRIHA rating, large commercial buildings are now growing, however, they do not use BIPV to improve the built environment. Most green buildings, which meet the GRIHA rating, use rooftop BAPV system, while external shading devices control the admitted daylight and heat for those large glazed façades [167]. Table 3 listed the availability of BIPV and BAPV products in India.

Table 3. Availability of BIPV/BAPV products in India.

\begin{tabular}{|l|l|l|}
\hline Product & Availability in Research Paper & Reference \\
\hline BIPV window & $\times$ & \\
\hline BIPV foil & $\times$ & \\
\hline BIPV tile & $\times$ & \\
\hline BAPVT (water/air) & $\checkmark$ & {$[168,169]$} \\
\hline BIPV/BAPV-(PCM) & $\checkmark$ & {$[170,171]$} \\
\hline BIPV/BAPV-LSC & $\times$ & \\
\hline BIPV/BAPV-CPC & $\times$ & \\
\hline
\end{tabular}

Future Pathway of BIPV/BAPV in India

Weak BIPV implementation and national planning, lack of energy policy and details of BIPV products, fewer BIPV experts and market professionals are the key responsible factors for slow or no progress of BIPV, for less-energy hungry building in India. The Indian Central government should motivate and support deployment of BIPV research and development by removing non-economic issues to BIPV uses, creating building codes for BIPV integration in building assembly. New training programs related to BIPV can educate the builders, developers, and engineers. Support from central or state-level government organizations, such as NISE, SECI, NIWE, MNRE, IIT, NITs and the state nodal agencies should work together.

Windows are one of the weakest components in a building. It allows external heat to come inside (enhance the air condition load), internal heat to outside (enhance heating load) and offer visual connection to building interior to exterior [172-185]. Building window systems are affected by an overall heat transfer coefficient ( $U$-value) and solar energy transmittance (g-value) [186-189]. For warmer place, high $U$-value and low g-value are required, while for colder area, low $U$-value and high g-value are suitable. Generally, single pane glass possesses higher $U$-value ( $U$-value $3-5 \mathrm{~W} / \mathrm{m}^{2} \mathrm{~K}$ ) and higher g-value followed by double ( $U$-value-2-3 W/m ${ }^{2} \mathrm{~K}$ g-value lower than single glass) and triple ( $U$-value $<2 \mathrm{~W} / \mathrm{m}^{2} \mathrm{~K}$; g-value lower than single and double) glass window [190-193]. This clear and highly transparent window is not able to limit the heat entering from exterior ambient of buildings. Thus, building interior temperature often crosses over occupants' comfort limit (thermal comfort temperature $18-20^{\circ} \mathrm{C}$ ). Hence, in order to maintain thermal comfort level, an excessive amount of grid power is consumed to run air-condition (AC). Integration of PV system into the single or double glass can create a single glass BIPV window or double glass BIPV window, which will, not only generate benevolent electricity, but also contro heat and restrict its flow into the exterior, where required, as shown in Figure 9. Semitransparent c-Si PV based BIPV windows can reduce 5.3\% heating and cooling load compared to standard BIPV [194] and has ability to limit up to $65 \%$ in total heat gains compared 
to traditional clear glass [195]. Previous investigation of BIPV window in cooling load dominated climate such as Singapore, Hongkong showed a positive impact on load reduction [196-198].

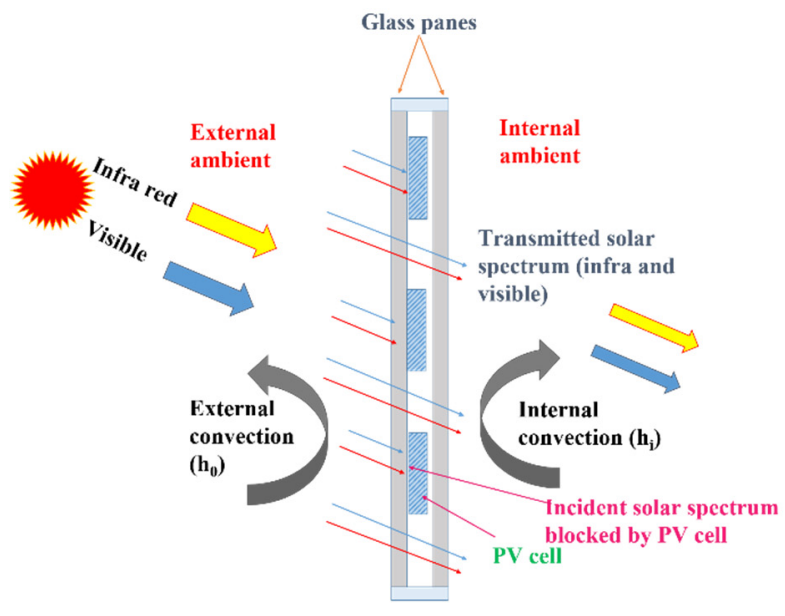

Semi-transparent BIPV window

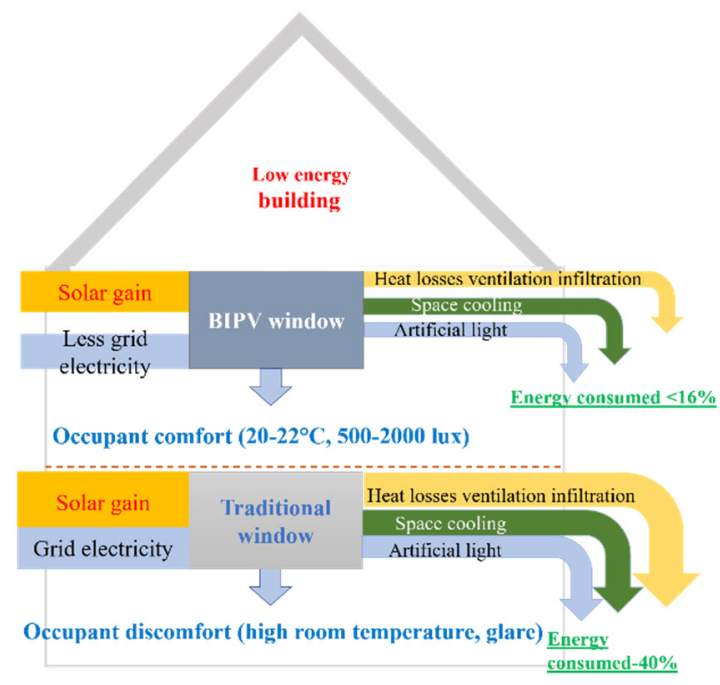

Sankey diagram for BIPV window

Figure 9. Schematic of a semitransparent BIPV window (left) and Sankey diagram while BIPV window is integrated into a building (right).

In India, buildings' AC load is excessively high, due to thehigh g-value of window. In summer, buildings' windows are closed, in order to abate hot air and sunlight $[199,200]$. This also creates a dearth of light in an indoor setting, which encourages occupants to employ artificial light. Small-to-medium office buildings use air conditioners during the day and peak summer, and are not in use at night or off-peak season. Hence, advanced single or double glass-based semitransparent BIPV window systems, which possess lower g-value compared to clear glass, are favorable in India as they can be particularly be influential in limiting excess usage of AC and lighting load for a less-energy hungry building.The inclusion of this semi-transparent BIPV window, not only lowers the g-value, but allows sufficient daylight and generates benign electricity concomitantly. India has primarily cooling load (AC load) demand climate, but can trim down this excessive grid power consumption by employing BIPV window to obtain less energy-hungry building. Also, replacing the traditional window system by BIPV window is easier than replacing other building components, such as roof or wall [201,202].

\section{Conclusions}

The following conclusion can be drawn from this review article:

- Building integrated photovoltaic (BIPV) replaces traditional building envelop, such as window, wall, roof and most often they are thin film, or third-generation based transparent or semi-transparent in nature.

- Building attached/applied photovoltaic (BAPV) indicates when PV systems are attached to a building without replacing its traditional envelops.

- India's solar mission which geared up from 2015, accelerated the rooftop PV integration. For building, the rooftop application's majority are BAPV types and capacity higher than kW level. India's total installed solar capacity reached only 33.8 GW by the end of September 2019, which is way behind to achieve India's 40 GW rooftop PV power generation by 2022.

- New technologies, such as PV tiles, foil and windows, as part of BIPV or BPAV, are not popular in India. 
- Indian electricity market needs a complete reform to allow smooth penetration of BIPV/BAPV in building. Also, due to rapid urbanization and development of zero and sustainable building industry, BIPV will keep pace in India soon.

- Single and double glass BIPV window systems have been identified as one of the most potential candidates for India.

Author Contributions: Conceptualization, A.G.; methodology, A.G.; investigation, P.R., M.V.N.S.G., A.K., S.N., A.G.; resources, P.R., S.N., A.G.; writing—original draft preparation, P.R., A.G.; writing—review and editing, S.N., A.G.; supervision, A.G.; project administration, A.G.; funding acquisition, A.G. All authors have read and agreed to the published version of the manuscript.

Funding: This work didn't receive any specific grants.

Acknowledgments: The authors would like to thank the anonymous reviewers for their valuable comments which were useful to enhance the quality of paper.

Conflicts of Interest: The authors declare no conflict of interest.

\section{References}

1. Kumar Sahu, B. A study on global solar PV energy developments and policies with special focus on the top ten solar PV power producing countries. Renew. Sustain. Energy Rev. 2015, 43, 621-634. [CrossRef]

2. Shukla, A.K.; Sudhakar, K.; Baredar, P. A comprehensive review on design of building integrated photovoltaic system. Energy Build. 2016, 128, 99-110. [CrossRef]

3. Gupta, D.; Ghersi, F.; Vishwanathan, S.S.; Garg, A. Achieving sustainable development in India along low carbon pathways: Macroeconomic assessment. World Dev. 2019, 123, 104623. [CrossRef]

4. Muniyoor, K. Is there a trade-off between energy consumption and employment: Evidence from India. J. Clean. Prod. 2020, 255, 120262. [CrossRef]

5. Tang, X.; McLellan, B.C.; Zhang, B.; Snowden, S.; Höök, M. Trade-Off analysis between embodied energy exports and employment creation in China. J. Clean. Prod. 2016, 134, 310-319. [CrossRef]

6. Bano, F.; Kamal, M.A. Examining the role of building envelope for energy efficiency in office buildings in India. Archit. Res. 2016, 6, 107-115. [CrossRef]

7. Bhatt, M.S.; Rajkumar, N.; Jothibasu, S.; Sudirkumar, R.; Pandian, G.; Nair, K.R.C. Commercial and residential building energy labeling. J. Sci. Ind. Res. (India) 2005, 64, 30-34.

8. Manu, S.; Brager, G.; Rawal, R.; Geronazzo, A.; Kumar, D. Performance evaluation of climate responsive buildings in India-Case studies from cooling dominated climate zones. Build. Environ. 2019, 148, 136-156. [CrossRef]

9. Bandyopadhyay, S.; Pathak, C.R.; Dentinho, T.P. Urbanization and Regional Sustainability in South Asia; Springer Open Ltd.: Cham, Switzerland, 2020; ISBN 978-3-030-23795-0.

10. Zhang, S.; He, Y. Analysis on the development and policy of solar PV power in China. Renew. Sustain. Energy Rev. 2013, 21, 393-401. [CrossRef]

11. Thapar, S.; Sharma, S. Factors impacting wind and solar power sectors in India: A survey-based analysis. Sustain. Prod. Consum. 2020, 21, 204-215. [CrossRef]

12. Righini, G.C.; Enrichi, F. Solar Cells' Evolution and Perspectives: A Short Review; Elsevier Ltd.: Amsterdam, The Netherlands, 2020; ISBN 9780081027622.

13. Røyset, A.; Kolås, T.; Jelle, B.P. Coloured building integrated photovoltaics: Influence on energy efficiency. Energy Build. 2020, 208. [CrossRef]

14. Peharz, G.; Ulm, A. Quantifying the influence of colors on the performance of c-Si photovoltaic devices. Renew. Energy 2018, 129, 299-308. [CrossRef]

15. Saga, T. Advances in crystalline silicon solar cell technology for industrial mass production. NPG Asia Mater. 2010, 2, 96-102. [CrossRef]

16. Liu, Z.; Sofia, S.E.; Laine, H.S.; Woodhouse, M.; Wieghold, S.; Peters, I.M.; Buonassisi, T. Revisiting thin silicon for photovoltaics: A technoeconomic perspective. arXiv 2019, arXiv:1906.06770. [CrossRef]

17. Battaglia, C.; Cuevas, A.; De Wolf, S. High-Efficiency crystalline silicon solar cells: Status and perspectives. Energy Environ. Sci. 2016, 9, 1552-1576. [CrossRef] 
18. Chen, Y.; Altermatt, P.P.; Chen, D.; Zhang, X.; Xu, G.; Yang, Y.; Wang, Y.; Feng, Z.; Shen, H.; Verlinden, P.J. From laboratory to production: Learning models of efficiency and manufacturing cost of industrial crystalline silicon and thin-film photovoltaic technologies. IEEE J. Photovolt. 2018, 8, 1531-1538. [CrossRef]

19. Ardente, F.; Latunussa, C.F.L.; Blengini, G.A. Resource efficient recovery of critical and precious metals from waste silicon PV panel recycling. Waste Manag. 2019, 91, 156-167. [CrossRef]

20. Hughes, L.; Bristow, N.; Korochkina, T.; Sanchez, P.; Gomez, D.; Kettle, J.; Gethin, D. Assessing the potential of steel as a substrate for building integrated photovoltaic applications. Appl. Energy 2018, 229, $209-223$. [CrossRef]

21. Chen, M.; Zhang, W.; Xie, L.; Ni, Z.; Wei, Q.; Wang, W.; Tian, H. Experimental and numerical evaluation of the crystalline silicon PV window under the climatic conditions in southwest China. Energy 2019, 183, 584-598. [CrossRef]

22. Akhsassi, M.; El Fathi, A.; Erraissi, N.; Aarich, N.; Bennouna, A.; Raoufi, M.; Outzourhit, A. Experimental investigation and modeling of the thermal behavior of a solar PV module. Sol. Energy Mater. Sol. Cells 2018, 180, 271-279. [CrossRef]

23. Gottschalg, R.; Betts, T.R.; Eeles, A.; Williams, S.R.; Zhu, J. Influences on the energy delivery of thin film photovoltaic modules. Sol. Energy Mater. Sol. Cells 2013, 119, 169-180. [CrossRef]

24. Taraba, M.; Adamec, J.; Danko, M.; Drgona, P.; Urica, T. Properties measurement of the thin film solar panels under adverse weather conditions. Transp. Res. Procedia 2019, 40, 535-540. [CrossRef]

25. Shah, A.V.; Schade, H.; Vanecek, M.; Meier, J.; Vallat-Sauvain, E.; Wyrsch, N.; Kroll, U.; Droz, C.; Bailat, J. Thin-Film silicon solar cell technology. Photovolt. Res. Appl. 2004, 12, 113-142. [CrossRef]

26. Sebastian, P.J.; Sivaramakrishnan, V. Electrical conduction and transmission electron microscopy studies of $\mathrm{CdSe}_{0.8} \mathrm{Te}_{0.2}$ thin films. Thin Solid Films 1991, 202, 1-9. [CrossRef]

27. Lee, T.D.; Ebong, A.U. A review of thin film solar cell technologies and challenges. Renew. Sustain. Energy Rev. 2017, 70, 1286-1297. [CrossRef]

28. Matsui, T.; Sai, H.; Bidiville, A.; Hsu, H.J.; Matsubara, K. Progress and limitations of thin-film silicon solar cells. Sol. Energy 2018, 170, 486-498. [CrossRef]

29. Stuckelberger, M.; Biron, R.; Wyrsch, N.; Haug, F.-J.; Ballif, C. Review: Progress in solar cells from hydrogenated amorphous silicon. Renew. Sustain. Energy Rev. 2017, 76, 1-27. [CrossRef]

30. Myong, S.Y.; Jeon, S.W. Efficient outdoor performance of esthetic bifacial a-Si: H semi-transparent PV modules. Appl. Energy 2016, 164, 312-320. [CrossRef]

31. Kichou, S.; Silvestre, S.; Nofuentes, G.; Torres-Ramírez, M.; Chouder, A.; Guasch, D. Characterization of degradation and evaluation of model parameters of amorphous silicon photovoltaic modules under outdoor long term exposure. Energy 2016, 96, 231-241. [CrossRef]

32. Sabri, L.; Benzirar, M. Effect of ambient conditions on thermal properties of photovoltaic cells: Crystalline and amorphous silicon. Int. J. Innov. Res. Sci. Eng. Technol. 2014, 3, 17815-17821. [CrossRef]

33. Staebler, D.L.; Wronski, C.R. Reversible conductivity changes in discharged-produced amorphous Si. Appl. Phys. Lett. 1977, 31, 274-292. [CrossRef]

34. Feurer, T.; Carron, R.; Torres Sevilla, G.; Fu, F.; Pisoni, S.; Romanyuk, Y.E.; Buecheler, S.; Tiwari, A.N. Efficiency improvement of near-stoichiometric $\mathrm{CuInSe}_{2}$ solar cells for application in tandem devices. Adv. Energy Mater. 2019, 9, 2-7. [CrossRef]

35. Kazmerski, L.L.; White, F.R.; Morgan, G.K. Thin-Film CuInSe 2 /CdS heterojunction solar cells. Appl. Phys. Lett. 1976, 29, 268-270. [CrossRef]

36. Stoichkov, V.; Sweet, T.K.N.; Jenkins, N.; Kettle, J. Studying the outdoor performance of organic building-integrated photovoltaics laminated to the cladding of a building prototype. Sol. Energy Mater. Sol. Cells 2019, 191, 356-364. [CrossRef]

37. Sato, R.; Chiba, Y.; Chikamatsu, M.; Yoshida, Y.; Taima, T.; Kasu, M.; Masuda, A. Investigation of the power generation of organic photovoltaic modules connected to the power grid for more than three years. Jpn. J. Appl. Phys. 2019, 58, 52001. [CrossRef]

38. Chemisana, D.; Moreno, A.; Polo, M.; Aranda, C.; Riverola, A.; Ortega, E.; Lamnatou, C.; Domènech, A.; Blanco, G.; Cot, A. Performance and stability of semitransparent OPVs for building integration: A benchmarking analysis. Renew. Energy 2019, 137, 177-188. [CrossRef]

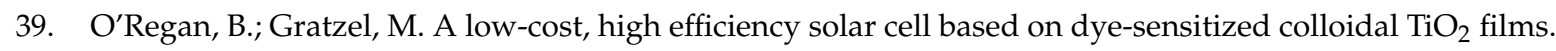
Nature 1991, 353, 737-740. [CrossRef] 
40. Sharma, S.; Siwach, B.; Ghoshal, S.K.; Mohan, D. Dye sensitized solar cells: From genesis to recent drifts. Renew. Sustain. Energy Rev. 2017, 70, 529-537. [CrossRef]

41. Kumara, N.T.R.N.; Lim, A.; Lim, C.M.; Petra, M.I.; Ekanayake, P. Recent progress and utilization of natural pigments in dye sensitized solar cells: A review. Renew. Sustain. Energy Rev. 2017, 78, 301-317. [CrossRef]

42. Ghosh, A.; Selvaraj, P.; Sundaram, S.; Mallick, T.K. The colour rendering index and correlated colour temperature of dye-sensitized solar cell for adaptive glazing application. Sol. Energy 2018, 163, 537-544. [CrossRef]

43. Cornaro, C.; Renzi, L.; Pierro, M.; Di Carlo, A.; Guglielmotti, A. Thermal and electrical characterization of a semi-transparent dye-sensitized photovoltaic module under real operating conditions. Energies 2018, 11, 155. [CrossRef]

44. Ghosh, A.; Bhandari, S.; Sundaram, S.; Mallick, T.K. Carbon counter electrode mesoscopic ambient processed \& characterised perovskite for adaptive BIPV fenestration. Renew. Energy 2020, 145, 2151-2158. [CrossRef]

45. Bhandari, S.; Roy, A.; Ghosh, A.; Mallick, T.K.; Sundaram, S. Performance of $\mathrm{WO}_{3}$-Incorporated carbon electrodes for ambient mesoscopic perovskite solar cells. ACS Omega 2019, 5, 422-429. [CrossRef] [PubMed]

46. Cannavale, A.; Ierardi, L.; Hörantner, M.; Eperon, G.E.; Snaith, H.J.; Ayr, U.; Martellotta, F. Improving energy and visual performance in offices using building integrated perovskite-based solar cells: A case study in Southern Italy. Appl. Energy 2017, 205, 834-846. [CrossRef]

47. Cannavale, A.; Hörantner, M.; Eperon, G.E.; Snaith, H.J.; Fiorito, F.; Ayr, U.; Martellotta, F. Building integration of semitransparent perovskite-based solar cells: Energy performance and visual comfort assessment. Appl. Energy 2017, 194, 94-107. [CrossRef]

48. Chen, Y.; Chen, D.; Liu, C.; Wang, Z.; Zou, Y.; He, Y.; Wang, Y.; Yuan, L.; Gong, J.; Lin, W.; et al. Mass production of industrial tunnel oxide passivated contacts (i-TOPCon) silicon solar cells with average efficiency over 23\% and modules over 345 W. Prog. Photovolt. Res. Appl. 2019, 1-8. [CrossRef]

49. Glunz, S.W.; Preu, R.; Biro, D. Crystalline Silicon Solar Cells: State-of-the-Art and Future Developments; Elsevier Ltd.: Amsterdam, The Netherlands, 2012; Volume 1, ISBN 9780080878737.

50. Zhang, T.; Wang, M.; Yang, H. A review of the energy performance and life-cycle assessment of building-integrated photovoltaic (BIPV) systems. Energies 2018, 11, 3157. [CrossRef]

51. Haegel, N.M.; Atwater, H.; Barnes, T.; Breyer, C.; Burrell, A.; Chiang, Y.-M.; De Wolf, S.; Dimmler, B.; Feldman, D.; Glunz, S.; et al. Terawatt-Scale photovoltaics: Transform global energy. Science 2019, 364, 836-838. [CrossRef]

52. Peng, J.; Lu, L.; Yang, H. Review on life cycle assessment of energy payback and greenhouse gas emission of solar photovoltaic systems. Renew. Sustain. Energy Rev. 2013, 19, 255-274. [CrossRef]

53. Tsai, C.Y.; Tsai, C.Y. See-through, light-through, and color modules for large-area tandem amorphous/microcrystalline silicon thin-film solar modules: Technology development and practical considerations for building-integrated photovoltaic applications. Renew. Energy 2020, 145, 2637-2646. [CrossRef]

54. Minemoto, T.; Fukushige, S.; Takakura, H. Difference in the outdoor performance of bulk and thin-film silicon-based photovoltaic modules. Sol. Energy Mater. Sol. Cells 2009, 93, 1062-1065. [CrossRef]

55. Han, J.; Lu, L.; Yang, H. Numerical evaluation of the mixed convective heat transfer in a double-pane window integrated with see-through a-Si PV cells with low-e coatings. Appl. Energy 2010, 87, 3431-3437. [CrossRef]

56. Zidane, T.E.K.; Adzman, M.R.B.; Tajuddin, M.F.N.; Mat Zali, S.; Durusu, A. Optimal configuration of photovoltaic power plant using grey wolf optimizer: A comparative analysis considering CdTe and c-Si PV modules. Sol. Energy 2019, 188, 247-257. [CrossRef]

57. Kumar, N.M.; Sudhakar, K.; Samykano, M. Performance evaluation of CdTe BIPV roof and façades in tropical weather conditions. Energy Sources Part A Recover. Util. Environ. Eff. 2019, 1-15. [CrossRef]

58. Bosio, A.; Rosa, G.; Romeo, N. Past, present and future of the thin film CdTe/CdS solar cells. Sol. Energy 2018, 31-43. [CrossRef]

59. Rawat, R.; Kaushik, S.C.; Sastry, O.S.; Bora, B.; Singh, Y.K. Long-Term performance analysis of CdTe PV module in real operating conditions. Mater. Today Proc. 2018, 5, 23210-23217. [CrossRef]

60. Barman, S.; Chowdhury, A.; Mathur, S.; Mathur, J. Assessment of the efficiency of window integrated CdTe based semi-transparent photovoltaic module. Sustain. Cities Soc. 2018, 37, 250-262. [CrossRef]

61. Ozden, T.; Akinoglu, B.G.; Turan, R. Long term outdoor performances of three different on-grid PV arrays in central Anatolia-An extended analysis. Renew. Energy 2017, 101, 182-195. [CrossRef] 
62. Powalla, M.; Dimmler, B. Development of large-area CIGS modules. Sol. Energy Mater. Sol. Cells 2003, 75 , 27-34. [CrossRef]

63. Dhere, N.G. Scale-Up issues of CIGS thin film PV modules. Sol. Energy Mater. Sol. Cells 2011, 95, $277-280$. [CrossRef]

64. Yalçin, L.; Öztürk, R. Performance comparison of c-Si, mc-Si and a-Si thin film PV by PVsyst simulation. J. Optoelectron. Adv. Mater. 2013, 15, 326-334. [CrossRef]

65. De Wild-Scholten, M.J. Energy payback time and carbon footprint of commercial photovoltaic systems. Sol. Energy Mater. Sol. Cells 2013, 119, 296-305. [CrossRef]

66. Theelen, M.; Foster, C.; Steijvers, H.; Barreau, N.; Vroon, Z.; Zeman, M. The impact of atmospheric species on the degradation of CIGS solar cells. Sol. Energy Mater. Sol. Cells 2015, 141, 49-56. [CrossRef]

67. Theelen, M.; Daume, F. Stability of $\mathrm{Cu}(\mathrm{In}, \mathrm{Ga}) \mathrm{Se}_{2}$ solar cells: A literature review. Sol. Energy 2016, 133, 586-627. [CrossRef]

68. Rudra, S.; Sarker, S.; Kim, D.M. Review on simulation of current-voltage characteristics of dye-sensitized solar cells. J. Ind. Eng. Chem. 2019, 80, 516-526. [CrossRef]

69. Gong, J.; Sumathy, K.; Qiao, Q.; Zhou, Z. Review on dye-sensitized solar cells (DSSCs): Advanced techniques and research trends. Renew. Sustain. Energy Rev. 2017, 68, 234-246. [CrossRef]

70. Mehmood, U.; Al-Ahmed, A.; Al-Sulaiman, F.A.; Malik, M.I.; Shehzad, F.; Khan, A.U.H. Effect of temperature on the photovoltaic performance and stability of solid-state dye-sensitized solar cells: A review. Renew. Sustain. Energy Rev. 2017, 79, 946-959. [CrossRef]

71. Howard, I.A.; Abzieher, T.; Hossain, I.M.; Eggers, H.; Schackmar, F.; Ternes, S.; Richards, B.S.; Lemmer, U.; Paetzold, U.W. Coated and printed perovskites for photovoltaic applications. Adv. Mater. 2019, 31, 1806702. [CrossRef]

72. Iqbal, T.; Shabbir, U.; Sultan, M.; Tahir, M.B.; Farooq, M.; Mansha, M.S.; Ijaz, M.; Maraj, M. All ambient environment-based perovskite film fabrication for photovoltaic applications. Int. J. Energy Res. 2019, 43, 806-813. [CrossRef]

73. Agresti, A.; Pescetelli, S.; Palma, A.L.; Martín-García, B.; Najafi, L.; Bellani, S.; Moreels, I.; Prato, M.; Bonaccorso, F.; Di Carlo, A. Two-Dimensional material interface engineering for efficient perovskite large-area modules. ACS Energy Lett. 2019, 1862-1871. [CrossRef]

74. Ballif, C.; Perret-Aebi, L.E.; Lufkin, S.; Rey, E. Integrated thinking for photovoltaics in buildings. Nat. Energy 2018, 3, 438-442. [CrossRef]

75. Peng, C.; Huang, Y.; Wu, Z. Building-Integrated photovoltaics (BIPV) in architectural design in China. Energy Build. 2011, 43, 3592-3598. [CrossRef]

76. Jelle, B.P.; Breivik, C.; Røkenes, H.D. Building integrated photovoltaic products: A state-of-the-art review and future research opportunities. Sol. Energy Mater. Sol. Cells 2012, 100, 69-96. [CrossRef]

77. Jelle, B.P. Building integrated photovoltaics: A concise description of the current state of the art and possible research pathways. Energies 2016, 9, 21. [CrossRef]

78. Shukla, A.K.; Sudhakar, K.; Baredar, P. Exergetic assessment of BIPV module using parametric and photonic energy methods: A review. Energy Build. 2016, 119, 62-73. [CrossRef]

79. Shukla, A.K.; Sudhakar, K.; Baredar, P. Recent advancement in BIPV product technologies: A review. Energy Build. 2017, 140, 188-195. [CrossRef]

80. Shukla, A.K.; Sudhakar, K.; Baredar, P.; Mamat, R. BIPV in Southeast Asian countries-Opportunities and challenges. Renew. Energy Focus 2017, 21, 25-32. [CrossRef]

81. Shukla, A.K.; Sudhakar, K.; Baredar, P.; Mamat, R. BIPV based sustainable building in South Asian countries. Sol. Energy 2018, 170, 1162-1170. [CrossRef]

82. Shukla, A.K.; Sudhakar, K.; Baredar, P.; Mamat, R. Solar PV and BIPV system: Barrier, challenges and policy recommendation in India. Renew. Sustain. Energy Rev. 2018, 82, 3314-3322. [CrossRef]

83. Ghosh, A.; Sundaram, S.; Mallick, T.K. Investigation of thermal and electrical performances of a combined semi-transparent PV-vacuum glazing. Appl. Energy 2018, 228, 1591-1600. [CrossRef]

84. Ghosh, A.; Sundaram, S.; Mallick, T.K. Colour properties and glazing factors evaluation of multicrystalline based semi-transparent Photovoltaic-vacuum glazing for BIPV application. Renew. Energy 2019, 131, 730-736. [CrossRef]

85. Wang, M.; Peng, J.; Li, N.; Yang, H.; Wang, C.; Li, X.; Lu, T. Comparison of energy performance between PV double skin facades and PV insulating glass units. Appl. Energy 2017, 194, 148-160. [CrossRef] 
86. Peng, J.; Curcija, D.C.; Lu, L.; Selkowitz, S.E.; Yang, H.; Zhang, W. Numerical investigation of the energy saving potential of a semi-transparent photovoltaic double-skin facade in a cool-summer Mediterranean climate. Appl. Energy 2016, 165, 345-356. [CrossRef]

87. Zhang, W.; Lu, L.; Peng, J.; Song, A. Comparison of the overall energy performance of semi-transparent photovoltaic windows and common energy-efficient windows in Hong Kong. Energy Build. 2016, 128, 511-518. [CrossRef]

88. Peng, J.; Lu, L.; Yang, H.; Ma, T. Comparative study of the thermal and power performances of a semi-transparent photovoltaic façade under different ventilation modes. Appl. Energy 2015, 138, 572-583. [CrossRef]

89. Alrashidi, H.; Ghosh, A.; Issa, W.; Sellami, N.; Mallick, T.K.; Sundaram, S. Evaluation of solar factor using spectral analysis for CdTe photovoltaic glazing. Mater. Lett. 2019, 237, 332-335. [CrossRef]

90. Alrashidi, H.; Ghosh, A.; Issa, W.; Sellami, N.; Mallick, T.K.; Sundaram, S. Thermal performance of semitransparent CdTe BIPV window at temperate climate. Sol. Energy 2020, 195, 536-543. [CrossRef]

91. Selvaraj, P.; Ghosh, A.; Mallick, T.K.; Sundaram, S. Investigation of semi-transparent dye-sensitized solar cells for fenestration integration. Renew. Energy 2019, 141, 516-525. [CrossRef]

92. Roy, A.; Ghosh, A.; Bhandari, S.; Selvaraj, P.; Sundaram, S.; Mallick, T.K. Color comfort evaluation of dye-sensitized solar cell (DSSC) based building-integrated photovoltaic (BIPV) glazing after 2 years of ambient exposure. J. Phys. Chem. C 2019, 123, 23834-23837. [CrossRef]

93. Sun, Y.; Shanks, K.; Baig, H.; Zhang, W.; Hao, X.; Li, Y.; He, B.; Wilson, R.; Liu, H.; Sundaram, S.; et al. Integrated semi-transparent cadmium telluride photovoltaic glazing into windows: Energy and daylight performance for different architecture designs. Appl. Energy 2018, 231, 972-984. [CrossRef]

94. Li, G.; Xuan, Q.; Akram, M.W.; Golizadeh Akhlaghi, Y.; Liu, H.; Shittu, S. Building integrated solar concentrating systems: A review. Appl. Energy 2020, 260, 114288. [CrossRef]

95. Rafiee, M.; Chandra, S.; Ahmed, H.; McCormack, S.J. An overview of various configurations of luminescent solar concentrators for photovoltaic applications. Opt. Mater. 2019, 91, 212-227. [CrossRef]

96. Baig, H.; Sellami, N.; Mallick, T.K. Performance modeling and testing of a building integrated concentrating photovoltaic (BICPV) system. Sol. Energy Mater. Sol. Cells 2015, 134, 29-44. [CrossRef]

97. Tian, M.; Su, Y.; Zheng, H.; Pei, G.; Li, G.; Riffat, S. A review on the recent research progress in the compound parabolic concentrator (CPC) for solar energy applications. Renew. Sustain. Energy Rev. 2018, 82, 1272-1296. [CrossRef]

98. Shanks, K.; Senthilarasu, S.; Mallick, T.K. Optics for concentrating photovoltaics: Trends, limits and opportunities for materials and design. Renew. Sustain. Energy Rev. 2016, 60, 394-407. [CrossRef]

99. Baig, H.; Heasman, K.C.; Mallick, T.K. Non-Uniform illumination in concentrating solar cells. Renew. Sustain. Energy Rev. 2012, 16, 5890-5909. [CrossRef]

100. Sarmah, N.; Mallick, T.K. Design, fabrication and outdoor performance analysis of a low concentrating photovoltaic system. Sol. Energy 2015, 112, 361-372. [CrossRef]

101. Sellami, N.; Mallick, T.K. Optical characterisation and optimisation of a static window integrated concentrating photovoltaic system. Sol. Energy 2013, 91, 273-282. [CrossRef]

102. Mallick, T.K.; Eames, P.C.; Hyde, T.J.; Norton, B. The design and experimental characterisation of an asymmetric compound parabolic photovoltaic concentrator for building façade integration in the UK. Sol. Energy 2004, 77, 319-327. [CrossRef]

103. Muhammad-Sukki, F.; Abu-Bakar, S.H.; Ramirez-Iniguez, R.; McMeekin, S.G.; Stewart, B.G.; Sarmah, N.; Mallick, T.K.; Munir, A.B.; Mohd Yasin, S.H.; Abdul Rahim, R. Mirror symmetrical dielectric totally internally reflecting concentrator for building integrated photovoltaic systems. Appl. Energy 2014, 113, 32-40. [CrossRef]

104. Selvaraj, P.; Baig, H.; Mallick, T.K.; Siviter, J.; Montecucco, A.; Li, W.; Paul, M.; Sweet, T.; Gao, M.; Knox, A.R.; et al. Enhancing the efficiency of transparent dye-sensitized solar cells using concentrated light. Sol. Energy Mater. Sol. Cells 2018, 175, 29-34. [CrossRef]

105. Baig, H.; Kanda, H.; Asiri, A.M.; Nazeeruddin, M.K.; Mallick, T. Increasing efficiency of perovskite solar cells using low concentrating photovoltaic systems. Sustain. Energy Fuels 2020, 1-10. [CrossRef]

106. Chandra, S.; Doran, J.; McCormack, S.J.; Kennedy, M.; Chatten, A.J. Enhanced quantum dot emission for luminescent solar concentrators using plasmonic interaction. Sol. Energy Mater. Sol. Cells 2012, 98, 385-390. [CrossRef] 
107. Chandra, S.; Doran, J.; McCormack, S.J. Two step continuous method to synthesize colloidal spheroid gold nanorods. J. Colloid Interface Sci. 2015, 459, 218-223. [CrossRef] [PubMed]

108. Chandra, S.; McCormack, S.J.; Kennedy, M.; Doran, J. Quantum dot solar concentrator: Optical transportation and doping concentration optimization. Sol. Energy 2015, 115, 552-561. [CrossRef]

109. Ter Schiphorst, J.; Cheng, M.L.M.K.H.Y.K.; van der Heijden, M.; Hageman, R.L.; Bugg, E.L.; Wagenaar, T.J.L.; Debije, M.G. Printed luminescent solar concentrators: Artistic renewable energy. Energy Build. 2020, 207, 27-30. [CrossRef]

110. Sethi, A.; Rafiee, M.; Chandra, S.; Ahmedj, H.; McCormack, S. A unified methodology for fabrication and quantification of gold nanorods, gold core silver shell nanocuboids and their polymer Nanocomposites. Langmuir 2019, 35. [CrossRef]

111. Aste, N.; Tagliabue, L.C.; Palladino, P.; Testa, D. Integration of a luminescent solar concentrator: Effects on daylight, correlated color temperature, illuminance level and color rendering index. Sol. Energy 2015, 114, 174-182. [CrossRef]

112. Aste, N.; Del Pero, C.; Tagliabue, L.C.; Leonforte, F.; Testa, D.; Fusco, R. Performance monitoring and building integration assessment of innovative LSC components. In Proceedings of the 5th International Conference on Clean Electrical Power: Renewable Energy Resources Impact, ICCEP 2015, Taormina, Italy, 16-18 June 2015; pp. 129-133. [CrossRef]

113. Fathi, M.; Abderrezek, M.; Djahli, F. Experimentations on luminescent glazing for solar electricity generation in buildings. Opt. Int. J. Light Electron. Opt. 2017, 148, 14-27. [CrossRef]

114. Vossen, F.M.; Aarts, M.P.J.; Debije, M.G. Visual performance of red luminescent solar concentrating windows in an office environment. Energy Build. 2016, 113, 123-132. [CrossRef]

115. Ahmed, H.; McCormack, S.J.; Doran, J. External quantum efficiency improvement with luminescent downshifting layers: Experimental and modelling. Int. J. Spectrosc. 2016, 2016, 1-7. [CrossRef]

116. Lamnatou, C.; Chemisana, D. Photovoltaic/Thermal (PVT) systems: A review with emphasis on environmental issues. Renew. Energy 2017, 105, 270-287. [CrossRef]

117. Shukla, A.; Kant, K.; Sharma, A.; Biwole, P.H. Cooling methodologies of photovoltaic module for enhancing electrical efficiency: A review. Sol. Energy Mater. Sol. Cells 2017, 160, 275-286. [CrossRef]

118. Phiraphat, S.; Prommas, R.; Puangsombut, W. Experimental study of natural convection in PV roof solar collector. Int. Commun. Heat Mass Transf. 2017, 89, 31-38. [CrossRef]

119. Hasanuzzaman, M.; Malek, A.B.M.A.; Islam, M.M.; Pandey, A.K.; Rahim, N.A. Global advancement of cooling technologies for PV systems: A review. Sol. Energy 2016, 137, 25-45. [CrossRef]

120. Kumar, A.; Baredar, P.; Qureshi, U. Historical and recent development of photovoltaic thermal (PVT) technologies. Renew. Sustain. Energy Rev. 2015, 42, 1428-1436. [CrossRef]

121. Calise, F.; Cappiello, F.L.; Dentice d'Accadia, M.; Vicidomini, M. Dynamic simulation, energy and economic comparison between BIPV and BIPVT collectors coupled with micro-wind turbines. Energy 2020, 191, 116439. [CrossRef]

122. Xu, L.; Luo, K.; Ji, J.; Yu, B.; Li, Z.; Huang, S. Study of a hybrid BIPV/T solar wall system. Energy 2020, 193, 116578. [CrossRef]

123. Debbarma, M.; Sudhakar, K.; Baredar, P. Comparison of BIPV and BIPVT: A review. Resour. Technol. 2016, 3, 263-271. [CrossRef]

124. Vats, K.; Tiwari, G.N. Performance evaluation of a building integrated semitransparent photovoltaic thermal system for roof and faade. Energy Build. 2012, 45, 211-218. [CrossRef]

125. Kamthania, D.; Nayak, S.; Tiwari, G.N. Performance evaluation of a hybrid photovoltaic thermal double pass facade for space heating. Energy Build. 2011, 43, 2274-2281. [CrossRef]

126. Agrawal, B.; Tiwari, G.N. Optimizing the energy and exergy of building integrated photovoltaic thermal (BIPVT) systems under cold climatic conditions. Appl. Energy 2010, 87, 417-426. [CrossRef]

127. Agathokleous, R.A.; Kalogirou, S.A. Double skin facades (DSF) and building integrated photovoltaics (BIPV): A review of configurations and heat transfer characteristics. Renew. Energy 2016, 89, 743-756. [CrossRef]

128. Yang, T.; Athienitis, A.K. A study of design options for a building integrated photovoltaic/thermal (BIPV/T) system with glazed air collector and multiple inlets. Sol. Energy 2014, 104, 82-92. [CrossRef]

129. Rajoria, C.S.; Agrawal, S.; Chandra, S.; Tiwari, G.N.; Chauhan, D.S. A Novel investigation of building integrated photovoltaic thermal (BiPVT) system: A comparative study. Sol. Energy 2016, 131, 107-118. [CrossRef] 
130. Kim, J.H.; Park, S.H.; Kang, J.G.; Kim, J.T. Experimental performance of heating system with buildingintegrated PVT (BIPVT) collector. Energy Procedia 2014, 48, 1374-1384. [CrossRef]

131. Browne, M.C.; Norton, B.; McCormack, S.J. Phase change materials for photovoltaic thermal management. Renew. Sustain. Energy Rev. 2015, 47, 762-782. [CrossRef]

132. Baetens, R.; Jelle, B.P.; Gustavsen, A. Phase change materials for building applications: A state-of-the-art review. Energy Build. 2010, 42, 1361-1368. [CrossRef]

133. Chandel, S.S.; Agarwal, T. Review of cooling techniques using phase change materials for enhancing efficiency of photovoltaic power systems. Renew. Sustain. Energy Rev. 2017, 73, 1342-1351. [CrossRef]

134. Deo, A.; Mishra, G.K.; Tiwari, G.N. A thermal periodic theory and experimental validation of building integrated semi-transparent photovoltaic thermal (BiSPVT) system. Sol. Energy 2017, 155, 1021-1032. [CrossRef]

135. Tewari, P.; Mathur, S.; Mathur, J.; Kumar, S.; Loftness, V. Field study on indoor thermal comfort of office buildings using evaporative cooling in the composite climate of India. Energy Build. 2019, 199, 145-163. [CrossRef]

136. Ali, M.; Jamil, B.; Fakhruddin. Estimating diffuse solar radiation in India: Performance characterization of generalized single-input empirical models. Urban Clim. 2019, 27, 314-350. [CrossRef]

137. Makade, R.G.; Chakrabarti, S.; Jamil, B.; Sakhale, C.N. Estimation of global solar radiation for the tropical wet climatic region of India: A theory of experimentation approach. Renew. Energy 2020, 146, 2044-2059. [CrossRef]

138. Lam, N.L.; Smith, K.R.; Gauthier, A.; Bates, M.N. Kerosene: A review of household uses and their hazards in low-and middle-income countries. J. Toxicol. Environ. Health Part B Crit. Rev. 2012, 15, 396-432. [CrossRef]

139. Singh, Y.; Pal, N. Obstacles and comparative analysis in the advancement of photovoltaic power stations in India. Sustain. Comput. Inform. Syst. 2020, 25, 100372. [CrossRef]

140. Behuria, P. The politics of late late development in renewable energy sectors: Dependency and contradictory tensions in India's National Solar Mission. World Dev. 2020, 126, 104726. [CrossRef]

141. Kapoor, K.; Pandey, K.K.; Jain, A.K.; Nandan, A. Evolution of solar energy in India: A review. Renew. Sustain. Energy Rev. 2014, 40, 475-487. [CrossRef]

142. Raina, G.; Sinha, S. Outlook on the Indian scenario of solar energy strategies: Policies and challenges. Energy Strateg. Rev. 2019, 24, 331-341. [CrossRef]

143. Goel, M. Solar rooftop in India: Policies, challenges and outlook. Green Energy Environ. 2016, 1, $129-137$. [CrossRef]

144. Yadav, S.K.; Bajpai, U. Energy, economic and environmental performance of a solar rooftop photovoltaic system in India. Int. J. Sustain. Energy 2020, 39, 51-66. [CrossRef]

145. Tarai, R.K.; Kale, P. Solar PV policy framework of Indian States: Overview, pitfalls, challenges, and improvements. Renew. Energy Focus 2018, 26, 46-57. [CrossRef]

146. Sethi, M. Climate change and urban areas. Clim. Chang. Urban Settl. 2018, 86, 1-44. [CrossRef]

147. Gupta, A.; Dalei, N.N. Energy, Environment and Globalization: An Interface; Springer: Singapore, 2020; ISBN 9789811393099.

148. Tulsyan, A.; Dhaka, S.; Mathur, J.; Yadav, J.V. Potential of energy savings through implementation of energy conservation building code in Jaipur city, India. Energy Build. 2013, 58, 123-130. [CrossRef]

149. Yu, S.; Tan, Q.; Evans, M.; Kyle, P.; Vu, L.; Patel, P.L. Improving building energy efficiency in India: State-Level analysis of building energy efficiency policies. Energy Policy 2017, 110, 331-341. [CrossRef]

150. Sharma, M. Development of a 'green building sustainability model' for green buildings in India. J. Clean. Prod. 2018, 190, 538-551. [CrossRef]

151. Chandel, S.S.; Sharma, A.; Marwaha, B.M. Review of energy efficiency initiatives and regulations for residential buildings in India. Renew. Sustain. Energy Rev. 2016, 54, 1443-1458. [CrossRef]

152. Ghosh, A.; Norton, B. Advances in switchable and highly insulating autonomous (self-powered) glazing systems for adaptive low energy buildings. Renew. Energy 2018, 126, 1003-1031. [CrossRef]

153. Ghosh, A.; Sarmah, N.; Sundaram, S.; Mallick, T.K. Numerical studies of thermal comfort for semi-transparent building integrated photovoltaic (BIPV)-vacuum glazing system. Sol. Energy 2019, 190, 608-616. [CrossRef]

154. Ravikumar, D.; Malghan, D. Material constraints for indigenous production of CdTe PV: Evidence from a Monte Carlo experiment using India's national solar mission benchmarks. Renew. Sustain. Energy Rev. 2013, 25, 393-403. [CrossRef] 
155. Hairat, M.K.; Ghosh, S. 100 GW solar power in India by 2022-A critical review. Renew. Sustain. Energy Rev. 2017, 73, 1041-1050. [CrossRef]

156. Rathore, P.K.S.; Rathore, S.; Pratap Singh, R.; Agnihotri, S. Solar power utility sector in india: Challenges and opportunities. Renew. Sustain. Energy Rev. 2018, 81, 2703-2713. [CrossRef]

157. Tomar, V.; Tiwari, G.N. Techno-Economic evaluation of grid connected PV system for households with feed in tariff and time of day tariff regulation in New Delhi-A sustainable approach. Renew. Sustain. Energy Rev. 2017, 70, 822-835. [CrossRef]

158. Rohankar, N.; Jain, A.K.; Nangia, O.P.; Dwivedi, P. A study of existing solar power policy framework in India for viability of the solar projects perspective. Renew. Sustain. Energy Rev. 2016, 56, 510-518. [CrossRef]

159. Jain, S.; Jain, N.K. Cost of electricity banking under open-access arrangement: A case of solar electricity in India. Renew. Energy 2020, 146, 776-788. [CrossRef]

160. Heeter, J.; Vora, R.; Mathur, S.; Madrigal, P.; Chatterjee, S.K.; Shah, R. Wheeling and Banking Strategies for Optimal Renewable Energy Deployment: International Experiences; A Clean Energy Regulators Initiative Report NREL/TP-6A20-65660; United States Department of Energy (DOE): Washington, DC, USA, 2016; Volume 1, pp. 1-56.

161. Rathore, P.K.S.; Chauhan, D.S.; Singh, R.P. Decentralized solar rooftop photovoltaic in India: On the path of sustainable energy security. Renew. Energy 2019, 131, 297-307. [CrossRef]

162. Satsangi, K.P.; Das, D.B.; Babu, G.S.S.; Saxena, A.K. Real time performance of solar photovoltaic microgrid in India focusing on self-consumption in institutional buildings. Energy Sustain. Dev. 2019, 52, 40-51. [CrossRef]

163. Nundy, S.; Ghosh, A.; Mallick, T.K. Hydrophilic and superhydrophilic self-cleaning coatings by morphologically varying $\mathrm{ZnO}$ microstructures for photovoltaic and glazing applications. ACS Omega 2020, 5, 1033-1039. [CrossRef]

164. Chanchangi, Y.N.; Ghosh, A.; Sundaram, S.; Mallick, T.K. Dust and PV performance in Nigeria: A review. Renew. Sustain. Energy Rev. 2020, 121, 109704. [CrossRef]

165. Smestad, G.P.; Germer, T.A.; Alrashidi, H.; Fernández, E.F.; Dey, S.; Brahma, H.; Sarmah, N.; Ghosh, A.; Sellami, N. Modelling photovoltaic soiling losses through optical characterization. Sci. Rep. 2020, 1-13. [CrossRef]

166. Kumar, A.; Prakash, O.; Dube, A. A review on progress of concentrated solar power in India. Renew. Sustain. Energy Rev. 2017, 79, 304-307. [CrossRef]

167. Bano, F.; Sehgal, V. Evaluation of energy-efficient design strategies: Comparison of the thermal performance of energy-efficient office buildings in composite climate, India. Sol. Energy 2018, 176, 506-519. [CrossRef]

168. Agrawal, B.; Tiwari, G.N. Life cycle cost assessment of building integrated photovoltaic thermal (BIPVT) systems. Energy Build. 2010, 42, 1472-1481. [CrossRef]

169. Gaur, A.; Tiwari, G.N.; Ménézo, C.; Al-Helal, I.M. Numerical and experimental studies on a building integrated semi-transparent photovoltaic thermal (BiSPVT) system: Model validation with a prototype test setup. Energy Convers. Manag. 2016, 129, 329-343. [CrossRef]

170. Karthick, A.; Kalidasa Murugavel, K.; Ghosh, A.; Sudhakar, K.; Ramanan, P. Investigation of a binary eutectic mixture of phase change material for building integrated photovoltaic (BIPV) system. Sol. Energy Mater. Sol. Cells 2020, 207, 110360. [CrossRef]

171. Karthick, A.; Murugavel, K.K.; Ramanan, P. Performance enhancement of a building-integrated photovoltaic module using phase change material. Energy 2018, 142, 803-812. [CrossRef]

172. Ghosh, A.; Norton, B. Optimization of PV powered SPD switchable glazing to minimise probability of loss of power supply. Renew. Energy 2019, 131, 993-1001. [CrossRef]

173. Nundy, S.; Ghosh, A. Thermal and visual comfort analysis of adaptive vacuum integrated switchable suspended particle device window for temperate climate. Renew. Energy 2019, in press. [CrossRef]

174. Ghosh, A.; Norton, B.; Mallick, T.K. Influence of atmospheric clearness on PDLC switchable glazing transmission. Energy Build. 2018, 172, 257-264. [CrossRef]

175. Ghosh, A.; Mallick, T.K. Evaluation of colour properties due to switching behaviour of a PDLC glazing for adaptive building integration. Renew. Energy 2018, 120, 126-133. [CrossRef]

176. Ghosh, A.; Norton, B.; Mallick, T.K. Daylight characteristics of a polymer dispersed liquid crystal switchable glazing. Sol. Energy Mater. Sol. Cells 2018, 174, 572-576. [CrossRef] 
177. Feng, Y.; Duan, Q.; Wang, J.; Baur, S. Approximation of building window properties using in situ measurements. Build. Environ. 2020, 160, 106590. [CrossRef]

178. Ghosh, A.; Norton, B. Interior colour rendering of daylight transmitted through a suspended particle device switchable glazing. Sol. Energy Mater. Sol. Cells 2017, 163, 218-223. [CrossRef]

179. Ghosh, A.; Norton, B.; Duffy, A. Effect of atmospheric transmittance on performance of adaptive SPD-vacuum switchable glazing. Sol. Energy Mater. Sol. Cells 2017, 161, 424-431. [CrossRef]

180. Ghosh, A.; Norton, B.; Duffy, A. Effect of sky clearness index on transmission of evacuated (vacuum) glazing. Renew. Energy 2017, 105, 160-166. [CrossRef]

181. Ghosh, A.; Norton, B.; Duffy, A. Effect of sky conditions on light transmission through a suspended particle device switchable glazing. Sol. Energy Mater. Sol. Cells 2017, 160, 134-140. [CrossRef]

182. Ghosh, A.; Norton, B. Durability of switching behaviour after outdoor exposure for a suspended particle device switchable glazing. Sol. Energy Mater. Sol. Cells 2017, 163, 178-184. [CrossRef]

183. Ghosh, A.; Mallick, T.K. Evaluation of optical properties and protection factors of a PDLC switchable glazing for low energy building integration. Sol. Energy Mater. Sol. Cells 2017, 176, 391-396. [CrossRef]

184. Ghosh, A.; Norton, B.; Duffy, A. First outdoor characterisation of a PV powered suspended particle device switchable glazing. Sol. Energy Mater. Sol. Cells 2016, 157, 1-9. [CrossRef]

185. Ghosh, A.; Norton, B.; Duffy, A. Daylighting performance and glare calculation of a suspended particle device switchable glazing. Sol. Energy 2016, 132, 114-128. [CrossRef]

186. Ghosh, A.; Norton, B.; Duffy, A. Measured overall heat transfer coefficient of a suspended particle device switchable glazing. Appl. Energy 2015, 159, 362-369. [CrossRef]

187. Ghosh, A.; Norton, B.; Duffy, A. Measured thermal \& daylight performance of an evacuated glazing using an outdoor test cell. Appl. Energy 2016, 177, 196-203. [CrossRef]

188. Ghosh, A.; Norton, B.; Duffy, A. Measured thermal performance of a combined suspended particle switchable device evacuated glazing. Appl. Energy 2016, 169, 469-480. [CrossRef]

189. Hemaida, A.; Ghosh, A.; Sundaram, S.; Mallick, T.K. Evaluation of thermal performance for a smart switchable adaptive polymer dispersed liquid crystal ( PDLC) glazing. Sol. Energy 2020, 195, 185-193. [CrossRef]

190. Michaux, G.; Greffet, R.; Salagnac, P.; Ridoret, J.B. Modelling of an airflow window and numerical investigation of its thermal performances by comparison to conventional double and triple-glazed windows. Appl. Energy 2019, 242, 27-45. [CrossRef]

191. Cuce, E. Accurate and reliable U-value assessment of argon-filled double glazed windows: A numerical and experimental investigation. Energy Build. 2018, 171, 100-106. [CrossRef]

192. Aguilar, J.O.; Xamán, J.; Olazo, Y.; Hernández-López, I.; Becerra, G.; Jaramillo, O.A. Thermal performance of a room with a double glazing window using glazing available in Mexican market. Appl. Therm. Eng. 2017, 119, 505-515. [CrossRef]

193. Li, D.; Li, Z.W.; Zheng, Y.M.; Liu, C.Y.; Lu, L.B. Optical performance of single and double glazing units in the wavelength 337-900 nm. Sol. Energy 2015, 122, 1091-1099. [CrossRef]

194. Wong, P.W.; Shimoda, Y.; Nonaka, M.; Inoue, M.; Mizuno, M. Semi-Transparent PV: Thermal performance, power generation, daylight modelling and energy saving potential in a residential application. Renew. Energy 2008, 33, 1024-1036. [CrossRef]

195. Lu, L.; Law, K.M. Overall energy performance of semi-transparent single-glazed photovoltaic (PV) window for a typical office in Hong Kong. Renew. Energy 2013, 49, 250-254. [CrossRef]

196. Ng, P.K.; Mithraratne, N.; Kua, H.W. Energy analysis of semi-transparent BIPV in Singapore buildings. Energy Build. 2013, 66, 274-281. [CrossRef]

197. Miyazaki, T.; Akisawa, A.; Kashiwagi, T. Energy savings of office buildings by the use of semi-transparent solar cells for windows. Renew. Energy 2005, 30, 281-304. [CrossRef]

198. Chow, T.T.; Pei, G.; Chan, L.S.; Lin, Z.; Fong, K.F. A comparative study of PV glazing performance in warm climate. Indoor Built Environ. 2009, 18, 32-40. [CrossRef]

199. Kiran Kumar, G.; Saboor, S.; Ashok Babu, T.P. Investigation of various wall and window glass material buildings in different climatic zones of India for energy efficient building construction. Mater. Today Proc. 2018, 5, 23224-23234. [CrossRef]

200. Gorantla, K.; Shaik, S.; Setty, A.B.T.P. Effect of different double glazing window combinations on heat gain in buildings for passive cooling in various climatic regions of India. Mater. Today Proc. 2017, 4, 1910-1916. [CrossRef] 
201. Skandalos, N.; Karamanis, D. PV glazing technologies. Renew. Sustain. Energy Rev. 2015, 49, $306-322$. [CrossRef]

202. Saifullah, M.; Gwak, J.; Yun, J.H. Comprehensive review on material requirements, present status, and future prospects for building-integrated semitransparent photovoltaics (BISTPV). J. Mater. Chem. A 2016, 4, 8512-8540. [CrossRef] 